\title{
Specifically designed magnetic biochar from waste wood for arsenic removal
}

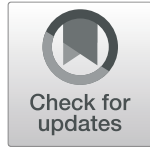

\author{
Chih-Kuei Chen ${ }^{1,2}$, Jia-Jia Chen ${ }^{1}$, Nhat-Thien Nguyen ${ }^{3}$, Thuy-Trang Le ${ }^{4}$, Nguyen-Cong Nguyen ${ }^{5}$ and \\ Chang-Tang Chang ${ }^{1 *}$ (i)
}

\begin{abstract}
Arsenic is a carcinogenic substance, with many cases of poisoning related to arsenic pollution in groundwater. In Taiwan arsenic in groundwater caused the notorious Blackfoot disease. Methods for arsenic removal from water include precipitation, membrane processes, ion exchange, and adsorption, but these processing technologies suffer from high investment costs and complex operations. The traditional adsorption method cannot be used for arsenic removal due to its high operating costs, difficulties in recovery, and low adsorption capacity. To address these issues, this study designed an adsorption material based on biochar for arsenic removal with higher adsorption properties and easy recovery. Biochar sources are readily available from waste wood as a cheap and environmentally friendly material. The efficiency of As (III) removal is also promoted by $\mathrm{FeCl}_{3}$ and $\mathrm{KMnO}_{4}$. The objectives of this research are to obtain optimum operation conditions by assessing the effects of different iron and manganese contents, different doses, different $\mathrm{pH}$ and different initial concentration. The adsorption mechanism between As (III) and biochar was studied by adsorption isotherms and the kinetic model. X-ray diffraction, energy-dispersive X-ray spectroscopy and elemental analyzer analysis results show that modified biochar has major elements of Fe and $\mathrm{Mn}$. There is greater magnetism, 40 emu $\mathrm{g}^{-1}$, in the modified biochar. The maximum adsorption efficiency of $81 \%$ and $0.72 \mathrm{mg} \mathrm{g}^{-1}$ capacity occurs when the ratio of $\mathrm{Mn}$, Fe and $\mathrm{C}$ is 4:1:1. The adsorption capacity is high under higher $\mathrm{pH}$ with pristine biochar and $1 \mathrm{FeC}$ under lower $\mathrm{pH}$ with $1 \mathrm{Fe} 2 \mathrm{MnC}$. The reaction mechanism is divided into four pathways. The first pathway is the attachment of As (III) ions into the pore of biochar via physical adsorption. In the second pathway, biochar can connect with As (III) through hydrogen bonding from the function group -OH in the biochar and the As (III) itself. In the third pathway, they can contact each other by electron force when the biochar surface is filled with a positive charge. In the fourth pathway, the compounds of manganese have strong oxidizability to oxidize As (III) to $\mathrm{As}(\mathrm{V})$. The iron ions then act as a bridge connecting the biochar and the As (III), resulting in the formation of new complex compounds.
\end{abstract}

Keywords: Magnetic biochar, FeMnC, FeC, Modification, Arsenic

\section{Introduction}

Arsenic is a concern in groundwater or wastewater treatment because of its health effects. Arsenic is classified as a substance that causes serious eye damage (Level 1), carcinogen (Level 1), a skin irritating substance (Level 2), reproductively toxic substances (Level 2) and a hazardous substance in water environment (Level 2).

\footnotetext{
* Correspondence: ctchang@niu.edu.tw

'Department of Environmental Engineering, National I-Lan University, I-Lan 26047, Taiwan

Full list of author information is available at the end of the article
}

Arsenic in nature occurs in two forms: inorganic and organic. Arsenic combined with elements such as oxygen, chlorine, and sulfur is referred to as inorganic arsenic, while, arsenic combined with carbon and hydrogen is referred to as organic arsenic [1]. Arsenic is predominantly found as As (III) $\left(\mathrm{H}_{2} \mathrm{AsO}_{3}{ }^{-}, \mathrm{HAsO}_{3}{ }^{2-}\right.$ and $\left.\mathrm{AsO}_{3}{ }^{3-}\right)$ and $\mathrm{As}(\mathrm{V})\left(\mathrm{H}_{2} \mathrm{AsO}_{4}{ }^{-}, \mathrm{HAsO}_{4}{ }^{2-}\right.$ and $\left.\mathrm{AsO}_{4}{ }^{3-}\right)$ in solutions [2]. In general, inorganic arsenic compounds are more toxic than organic arsenic compounds. In addition, As (III) is more toxic than $\mathrm{As}(\mathrm{V})$ because the former binds to single but with higher affinity for vicinal sulfhydryl groups

(c) The Author(s). 2021 Open Access This article is licensed under a Creative Commons Attribution 4.0 International License, which permits use, sharing, adaptation, distribution and reproduction in any medium or format, as long as you give appropriate credit to the original author(s) and the source, provide a link to the Creative Commons licence, and indicate if changes were made. The images or other third party material in this article are included in the article's Creative Commons licence, unless indicated otherwise in a credit line to the material. If material is not included in the article's Creative Commons licence and your intended use is not permitted by statutory regulation or exceeds the permitted use, you will need to obtain permission directly from the copyright holder. To view a copy of this licence, visit http://creativecommons.org/licenses/by/4.0/. 
that react with a variety of proteins and inhibit their activity. As (III) is more stable than $\mathrm{As}(\mathrm{V})$ because of its electronic configuration [3]. Arsenic is toxic and causes hyper pigmentation, skin-thickening, muscular weakness, neurological diseases, and cancer in humans. The main route of human exposure is through drinking arsenic contaminated groundwater. Therefore, the World Health Organization has lowered the arsenic standard for drinking water to $10 \mu \mathrm{g} \mathrm{L}^{-1}$ [4].

Arsenic removal technologies primarily include ion exchange, coagulation-precipitation, membrane separation, biological treatment, oxidation and adsorption as shown in Table 1. Ion exchange is often used to remove arsenic from wastewater. It uses ions or functional groups inside to combine with target arsenic in order to separate arsenic ions from wastewater [5]. This method of removing $\mathrm{As}(\mathrm{V})$ in water is much better than As (III) because $\mathrm{As}(\mathrm{V})$ exists in the form of ions while As (III) exist largely in the form of molecules [4]. Anirudhan and Unnithan [6] used a novel anion exchanger prepared from coconut coir pith to remove arsenic with an initial arsenic concentration of $1 \mathrm{mg} \mathrm{L}^{-1}$, with the removal efficiency reaching $99.2 \%$. The coagulation-sedimentation method is a traditional method of arsenic removal. This method involves adding coagulants in arsenic containing water. The stability of the colloid is destroyed by the chemical or physical reactions with arsenic. Aggregates of fine particles are produced and formed larger precipitation particles due to clustering. Separation of arsenic pollutants and water is also achieved through filtration [7]. Membrane separation technology is divided into the two types of high-pressure membrane technology, including reverse osmosis and nano-filtration, and lowpressure membrane technology, including ultra-filtration and microfiltration. The removal of arsenic from surface water by nano-filtration membrane was studied by Waypa et al. [8], who found the removal efficiency reached 99\%. Biological methods are a promising alternative to traditional arsenic removal techniques. These methods reduce toxicity by enriching the arsenic in water by itself or its metabolites or transforming As (III) into $\mathrm{As}(\mathrm{V})$ [9]. Kao et al. [10] found bacteria, designated
As-7325, which can oxidize As (III) into As(V) within 3 days. After that, the As $(\mathrm{V})$ was released by the metabolic products of bacteria through the process of adsorption or co-precipitation. Oxidation methods commonly include chemical oxidation and photo-catalytic oxidation. $\mathrm{O}_{3}, \mathrm{H}_{2} \mathrm{O}_{2}, \mathrm{Cl}_{2}$ and others are chemical oxidants. Pincus et al. [11] examined the oxidation of As (III) to $\mathrm{As}(\mathrm{V})$ by $\mathrm{Cu}^{2+}$ in the presence of dissolved oxygen to elucidate the potential and mechanisms of $\mathrm{Cu}^{2+}$ and $\mathrm{Cu}^{2+}-\mathrm{n}-\mathrm{TiO}_{2}$ involvement in Fenton-like reactions. The results showed that the amount of As (III) oxidized to $\mathrm{As}(\mathrm{V})$ is strongly regulated by the $\mathrm{Cu}^{2+}$ loading, with a higher $\mathrm{Cu}^{2+}$ loading leading to more oxidized As (III) form and greater binding to the adsorbent surface as $\mathrm{As}(\mathrm{V})[11]$. The adsorption method for treating arsenic-containing wastewater mainly uses physical, chemical or ion exchange processes to fix arsenic on the adsorbent surface. It may then be separated from the water together with the adsorbents. Adsorbents used for this purpose include activated carbon, modified biochar, metal hydroxide, inorganic nano-metal oxides and their composites. The adsorbents require a large specific surface area, an abundant porous structure and strong function groups [12].

Biochar has been identified as an effective adsorbent that can be used to remove various aqueous heavy metals, because the specific surface area and microporous structures of biochar are high. It hosts several surface functional groups, such as carboxyl $(-\mathrm{COOH})$, hydroxyl $(-\mathrm{OH})$ and amino $\left(-\mathrm{NH}_{2}\right)$, for adsorbing heavy metal effectively [13]. These groups can work through electron donation, cation exchange, electrostatic attraction, or surface complexation to remove heavy metals [14]. Recent studies have focused on the use of potential adsorbents, including the use of hard wood [15], peanut hull [16], natural lignocelluloses materials [17], cottonwood [18], animal waste [19], corn straw [20], coconut shell [21], walnut shells [22], hazelnut [23], cotton stems [24] and sawdust or rice straw [25] as cheap and environment friendly materials. Therefore, in this research, a novel adsorbent with higher adsorption properties and easy recovery for arsenic removal was prepared from waste wood of a wood processing factory. The objectives

Table 1 Comparison for the removal of arsenic by different technologies

\begin{tabular}{llll}
\hline Method & Operation & Cost & As removal efficiency \\
\hline lon exchange & Complex & Expensive & Good \\
Coagulation precipitation & Complex & Expensive & Average \\
Membrane separation & Complex & Expensive & Good \\
Biological treatment & Complex & Average & Average \\
Oxidation & Complex & Expensive & Average \\
Activated carbon adsorption & Easy & Average & Average \\
Biochar adsorption & Easy & Cheap & Good \\
\hline
\end{tabular}


of this work are to analyze (a) the preparation of biochar and modified biochar; (b) the characteristics analysis of material; (c) the effect of $\mathrm{pH}$, initial concentration and dosage; (d) the adsorption isotherm and adsorption kinetics; and (e) the mechanism of arsenic removal.

\section{Materials and methods}

\section{Preparation of pristine biochar (PB)}

$\mathrm{PB}$ was prepared by the pyrolysis method from wood biomass obtained from a wood processing factory. First, a crusher was used to crush the wood biomass, and the size after crushing was about $0.1-0.5 \mathrm{~cm}$. After that, the biomass was washed three times using tap water to remove the dirt, such as soil, plastics and dust. Then, it was washed continually using the deionized water to eliminate the influence of other metal ions. It was then dried in an oven at a temperature of $333 \mathrm{~K}$ for the duration of $48 \mathrm{~h}$. Next, it was kept in a muffle furnace at the heat-up speed of $300 \mathrm{~K} \mathrm{~min}^{-1}$ and a pyrolysis temperature of $873 \mathrm{~K}$ for $1 \mathrm{~h}$. Then, it was taken out from the muffle furnace when it had cooled and was washed using the deionized water twice to remove floating objects. After filtering and drying, the PB was obtained.

\section{Preparation of $\mathbf{x F e C}$}

To improve the efficiency of magnetism and adsorption, $\mathrm{FeCl}_{3}$ is used to modify the PB in this study. The preparation procedures for magnetic biochar before obtaining the pre-treated biomass are same as for the PB. To obtain the $x \mathrm{FeC}$ material, different amounts of $\mathrm{FeCl}_{3}(x=5$, 10,20 and $40 \mathrm{~g}$ ) and $10 \mathrm{~g}$ of the PB were dissolved in $200 \mathrm{~mL}$ of distilled water, and stirred for $2 \mathrm{~h}$. After that, the mixture was heated in a water bath and dried in an oven to remove the water to a suitable extent. Further, it was kept in a muffle furnace for pyrolysis under the same conditions as the PB. The material obtained when the procedures were completed was Fe modified biochar represented as $x \mathrm{FeC}$. The value of ' $x$ ' depends on the weight ratio of $\mathrm{FeCl}_{3}$ and biomass. For example, $0.5 \mathrm{FeC}$, $1 \mathrm{FeC}, 2 \mathrm{FeC}$ and $4 \mathrm{FeC}$ represent the weight ratios of $\mathrm{FeCl}_{3}$ at 5, 10, 20 and $40 \mathrm{~g}$, respectively, when the weight of the PB is $10 \mathrm{~g}$.

\section{Preparation of xFeyMnC}

$x$ Fe $y \mathrm{MnC}$ was prepared following the method described above. To obtain the $x \mathrm{Fe} y \mathrm{MnC}$ material, different amounts of $\mathrm{KMnO}_{4}(y=5,10,20$ and $40 \mathrm{~g})$ and $10 \mathrm{~g}$ of $x \mathrm{FeC}$ were dissolved in $200 \mathrm{~mL}$ of distilled water, and stirred for $2 \mathrm{~h}$. After that, the mixture was heated in a water bath and dried in an oven to remove the water to a suitable extent. Further, it was kept in a muffle furnace for pyrolysis under the same conditions as the $x \mathrm{FeC}$. The material obtained was Mn modified biochar represented as $x \mathrm{Fe} y \mathrm{MnC}$. The value of ' $x$ ' depends on the weight ratio of $\mathrm{FeCl}_{3}$ with $\mathrm{PB}$ and the value of ' $y$ ' depends on the weight ratio of $\mathrm{KMnO}_{4}$ with $x \mathrm{FeC}$. For example, $x \mathrm{Fe} 0.5 \mathrm{MnC}, x \mathrm{Fe} 1 \mathrm{MnC}, x \mathrm{Fe} 2 \mathrm{MnC}$ and $x \mathrm{Fe} 4 \mathrm{MnC}$ represent weight ratios of $\mathrm{KMnO}_{4}$ at 5, 10, 20 and $40 \mathrm{~g}$, respectively, when the weight of $x \mathrm{FeC}$ is $10 \mathrm{~g}$. The preparation method of Lin et al. [26] was used in this research.

\section{Characterization}

The pore size distribution, pore volume and specific surface area were determined by performing $\mathrm{N}_{2}$ adsorptiondesorption measurements with an ASAP 2020 apparatus by using Brunauer-Emmett-Teller (BET) calculation methods. The morphology of the material was measured through a scanning electron microscopy (SEM) with energy dispersive X-ray spectroscopy (EDS) analysis. The crystal phase of the material was determined by an Xray diffraction (XRD) with employing $\mathrm{CuK \alpha}$ radiation wavelength of $0.15405 \mathrm{~nm}$, accelerating voltage of $40 \mathrm{kV}$ and current of $30 \mathrm{~mA}$ over the $2 \theta$ range of $20-80^{\circ}$. The magnetic performance of biochar was carried out at room temperature with a vibrating sample magnetometer (VSM). The fourier transform infrared (FTIR) of the biochar carbon was recorded to study the functional groups at room temperature.

\section{Adsorption performance assessment}

Adsorption performance assessment was carried out in $100 \mathrm{~mL}$ adsorption system. The biochar was mixed with $80 \mathrm{~mL}$ of the appropriate As (III) solution under $25^{\circ} \mathrm{C}$ for $24 \mathrm{~h}$. As (III) solutions were prepared by adding $\mathrm{As}_{2} \mathrm{O}_{3}$ from High-Purity Standards Company. Afterward, the solution was filtered with using a membrane filter (pore size $0.45 \mu \mathrm{m}$ ). In addition, the residual As (III) in the aqueous solutions was determined by high performance liquid chromatography connected with inductively coupled plasma atomic emission spectroscopy (ICPAES). The ICP-AES detection limit for arsenic detection is $10 \mathrm{ppb}$. The test results were regularly tested with standard solution up to $20 \mathrm{ppb}$ to get the accurate data.

The capacity adsorption of As was calculated as follows:

$$
\begin{aligned}
& q_{e}=\frac{C_{o}-C_{e}}{W} \times \mathrm{V} \\
& R_{e}=\frac{C_{o}-C_{e}}{C_{o}} \times 100 \%
\end{aligned}
$$

where $q_{e}\left(\mathrm{mg} \mathrm{g}^{-1}\right)$ is the equilibrium adsorption capacity, $C_{o}\left(\mathrm{mg} \mathrm{L}^{-1}\right)$ is the initial concentration of As, $C_{e}(\mathrm{mg}$ $\mathrm{L}^{-1}$ ) stands for the equilibrium concentration measured after adsorption, $W(\mathrm{mg})$ is the amount of adsorbent 
used in the experiments, $\mathrm{V}(\mathrm{mL})$ is the volume of As solution and $R_{e}$ is removal efficiency of As by biochar.

\section{Test for the influence of biochar types}

To investigate the difference of modified biochar and unmodified biochar, the samples of $\mathrm{PB}, 0.5 \mathrm{FeC}, 1 \mathrm{FeC}$, $2 \mathrm{FeC}, 4 \mathrm{FeC}, 1 \mathrm{Fe} 0.5 \mathrm{MnC}, 1 \mathrm{Fe} 1 \mathrm{MnC}, 1 \mathrm{Fe} 2 \mathrm{MnC}$ and 1 Fe $4 \mathrm{MnC}(0.08 \mathrm{~g})$ were mixed with $80 \mathrm{~mL}$ As (III) solution $\left(1.0 \mathrm{mg} \mathrm{L}^{-1}\right)$ in a $100 \mathrm{~mL}$ plastic bottle, respectively. Under the same conditions as above, samples were collected periodically up to $1440 \mathrm{~min}$, filtered and measured by the ICP-AES. The Eqs. (1) and (2) were used to calculate the adsorption capacity and adsorption efficiency of the nine different types of biochar for As (III) removal.

\section{Test for the influence of $\mathrm{pH}$}

To explore the influence of solution $\mathrm{pH}$, the $\mathrm{pH}$ of the As (III) solution $\left(1.0 \mathrm{mg} \mathrm{L}^{-1}\right)$ was set to $3.0,5.0,7.0,9.0$ and 11.0 , respectively, adjusted by $1.0 \mathrm{M} \mathrm{HCl}$ solution or $1.0 \mathrm{M} \mathrm{NaOH}$ solution. Three types of biochar samples, including $\mathrm{PB}, 1 \mathrm{FeC}$ and $1 \mathrm{Fe} 2 \mathrm{MnC}$ weighing $0.08 \mathrm{~g}$ each, were put into the prepared solutions $(80 \mathrm{~mL})$ of different $\mathrm{pH}$. The mixed solution was then shaken at $160 \mathrm{rpm}$ for $24 \mathrm{~h}$ in the water bath shaker and taken out for analysis.

For additional identification of the biochar, its point of zero charge $\left(\mathrm{pH}_{\mathrm{pzc}}\right)$ was determined. Thus, a $0.01 \mathrm{M}$ $\mathrm{NaCl}$ solution, different initial $\mathrm{pH}\left(\mathrm{pH}_{\text {Initial }}\right)$ and $0.08 \mathrm{~g}$ of $\mathrm{PB}, 1 \mathrm{FeC}$ and $1 \mathrm{Fe} 2 \mathrm{MnC}$ were employed. The asprepared biochar was suspended in each $25 \mathrm{~mL}$ of $\mathrm{NaCl}$ solution of a pre-adjusted $\mathrm{pH}$, and allowed to stir at $25^{\circ} \mathrm{C}$ for $24 \mathrm{~h}$. The final $\mathrm{pH}\left(\mathrm{pH}_{\text {Final }}\right)$ of the supernatant was measured after the oxide suspension separation. The $\mathrm{pH}_{\text {Initial }}-\mathrm{pH}_{\text {Final }}$ curve was drawn using the measured $\mathrm{pH}_{\text {Initial }}$ and $\mathrm{pH}_{\text {Final }}$ values. From the intersection between this curve and the $\mathrm{pH}_{\text {Initial }}=\mathrm{pH}_{\text {Final }}$ line, the $\mathrm{pH}_{\mathrm{pzc}}$ of the as-prepared biochar may be estimated.

\section{Test for the influence of as concentration}

To investigate the influence of As (III) concentration, the initial concentration was varied from 0.25 to 50.0 $\mathrm{mg} \mathrm{L}^{-1}$. The three types of biochar sample $(0.08 \mathrm{~g})$ including $\mathrm{PB}, 1 \mathrm{FeC}$ and $1 \mathrm{Fe} 2 \mathrm{MnC}$ were added into the $\mathrm{As}$ (III) solution with various concentrations of $0.25,0.5$, 1.0, 2.0, 5.0, 10.0 and $50.0 \mathrm{mg} \mathrm{L}^{-1}$, respectively. In this study, the mixture of biochar and As (III) solution was shaken at $160 \mathrm{rpm}$ for $24 \mathrm{~h}$ in the water bath shaker and taken out for analysis.

\section{Test for the influence of biochar dosage}

To find the impact of biochar dosage, the dosages of three different types of biochar were varied from $0.2 \mathrm{~g}$ $\mathrm{L}^{-1}$ to $1.2 \mathrm{~g} \mathrm{~L}^{-1}$. The initial concentration of As (III) was fixed at $1.0 \mathrm{mg} \mathrm{L}^{-1}$ and the dosages of $\mathrm{PB}, 1 \mathrm{FeC}$ and $1 \mathrm{Fe} 2 \mathrm{MnC}$ were $0.2,0.4,0.6,0.8,1.0$ and $1.2 \mathrm{~g} \mathrm{~L}^{-1}$, respectively. This means that the added weight of biochar is $0.016,0.032,0.048,0.064,0.080$ and $0.096 \mathrm{~g}$ corresponding to the designed dosage with $80 \mathrm{~mL}$ solution. After shaking the mixture at $160 \mathrm{rpm}$ for $24 \mathrm{~h}$, the solids were removed by filtration and the residual liquid was measured by ICP-AES.

\section{Test for the influence of recycle times}

In this section, the application potential of $\mathrm{PB}, 1 \mathrm{FeC}$ and $1 \mathrm{Fe} 2 \mathrm{MnC}$ were evaluated. The As (III) species adsorptiondesorption recycles on $\mathrm{PB}, 1 \mathrm{FeC}$ and $1 \mathrm{Fe} 2 \mathrm{MnC}$ were carried out by $\mathrm{NaOH}$ regeneration with initial concentration 1.0 $\mathrm{mg} \mathrm{L}^{-1}$ and $0.08 \mathrm{~g}$ of biochar for $24 \mathrm{~h}$ contact time. Most of the adsorbed As (III) species could be desorbed from biochar by alkaline at $\mathrm{pH}$ 11.5, which is good accordance with the results about the effect of $\mathrm{pH}$ on As (III) species adsorption. The solids were removed by magnet adsorption and the residual liquid was measured by ICP-AES.

\section{The methods of kinetics models analysis Pseudo-first-order}

The pseudo-first-order equation is given as Eq. (3) [27].

$$
\frac{d q_{t}}{d_{t}}=k_{1}\left(q_{e}-q_{t}\right)
$$

where, $q_{t}$ is adsorption capacity $\left(\mathrm{mg} \mathrm{g}^{-1}\right)$ at the time of " $t$ "; $q_{e}$ is adsorption capacity $\left(\mathrm{mg} \mathrm{g}^{-1}\right) ; k_{1}$ is rate coefficient of the first-order adsorption mode $\left(\mathrm{min}^{-1}\right)$; and $t$ is time ( $\mathrm{min})$.

After the Eq. (3) is integrated, the function formula can be obtained as Eq. (4).

$$
\ln \left(\mathrm{q}_{\mathrm{e}}-\mathrm{q}_{\mathrm{t}}\right)=\ln q_{e}-k_{1} t
$$

\section{Pseudo-second-order}

The pseudo-second-order model is represented as Eq. (5) [28].

$$
\frac{d q_{t}}{d_{t}}=k_{2}\left(q_{e}-q_{t}\right)^{2}
$$

where, $k_{2}$ is rate coefficient of the second-order adsorption mode $\left(\mathrm{mg} \mathrm{g}^{-1} \mathrm{~min}^{-1}\right)$.

After arranging the above equation, the Eq. (6) can be obtained as shown followed.

$$
\frac{t}{q_{t}}=\frac{1}{k_{2} q_{e}{ }^{2}}+\frac{t}{q_{e}}
$$


Isothermal adsorption models analysis

\section{Langmuir model}

Based on the above assumptions, Langmuir adsorption Eq. (7) is derived as follows [29].

$$
Q=\frac{a b \times C_{o}}{1+a C_{o}}
$$

After taking the inverse of the above equation, Eq. (8) can be obtained

$$
\frac{1}{Q}=\frac{1}{b}+\frac{1}{a b \times C_{o}}
$$

where, $C_{o}$ is the initial concentration in the solution and $Q$ is the amount of adsorbed by the additive. $a$ and $b$ are Langmuir constants related to adsorption capacity and adsorption energy, respectively. Plotting $Q^{-1}$ versus $C_{o}^{-}$ ${ }^{1}$, and measuring the slope and intercept of the plot, $a$ and $b$ can be directly interpreted.

\section{Freundlich model}

The empirical formula of constant temperature adsorption is proposed, as shown below [30].

$$
Q=K C_{o^{\frac{1}{n}}}
$$

Taking the natural logarithm of both sides gives:

$$
\ln Q=\ln K+\frac{1}{n}\left(\ln C_{0}\right)
$$

If experiment absorption matches the above empirical model, then by plotting $\ln Q$ versus $\ln C_{o}$ the values of the Freundlich constants of $K$ and $n$ can be directly interpreted from the plot as the intercept and slope.

\section{Temkin model}

Temkin isotherm model takes adsorbate-adsorbent interactions into account. It is assumed that the relationship between adsorption capacity and pollutant concentration at equilibrium state is linear rather than logarithmic which is different from Freundlich equation. Besides, the adsorption heat decreases linearly rather than exponentially as all adsorbents gradually cover the adsorbent is also assumed [31].

The Eq. (11) for the linear form of Temkin model can be shown as follows:

$$
Q=B\left(\ln K_{T}+\ln C_{o}\right)
$$

here, $B$ is Temkin constant related to heat of adsorption $\left(\mathrm{J} \mathrm{mol}^{-1}\right)$; and $K_{T}$ is Equilibrium binding energy constant $\left(\mathrm{Jg}^{-1}\right)$.

\section{Thermodynamics analysis}

Thermodynamic behaviors are interpreted by the thermodynamic parameters including the change in standard Gibbs free energy $\left(\Delta G^{0}\right)$, standard enthalpy $\left(\Delta H^{0}\right)$, and standard entropy $\left(\Delta S^{0}\right)$. These parameters are calculated by the following Eqs [32].:

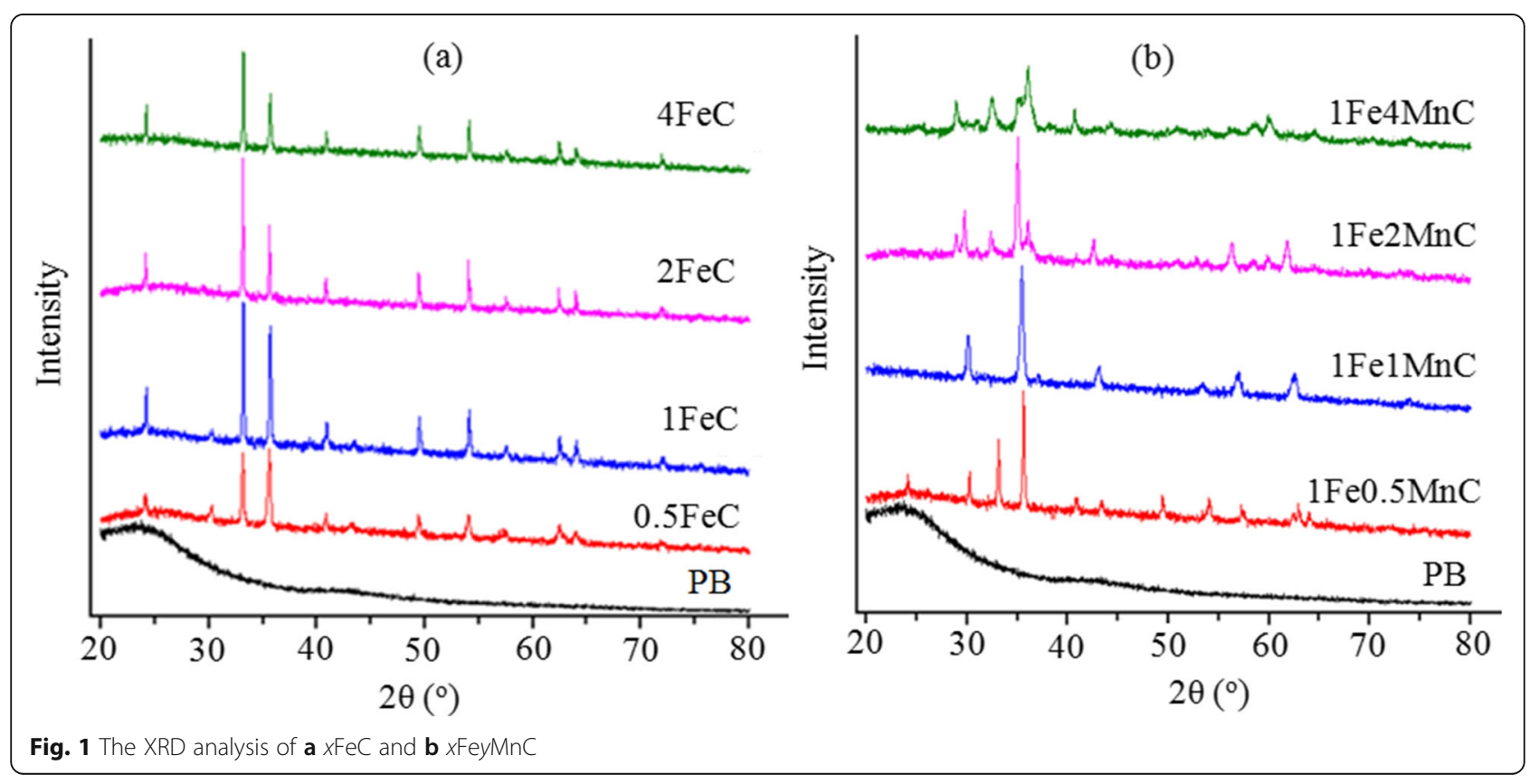




$$
\begin{aligned}
& \Delta G^{o}=-R T \ln K_{L} \\
& \ln K_{L}=\frac{\Delta S^{o}}{R T}-\frac{\Delta H^{o}}{R T}
\end{aligned}
$$

where, $K_{L}\left(\mathrm{~L} \mathrm{~mol}^{-1}\right)$ is the Langmuir equilibrium constant of the adsorption process. $R\left(\mathrm{~J} \mathrm{~mol}^{-1} \mathrm{~K}^{-1}\right)$ and $T$ (K) are gas constant and absolute temperature, respectively.

\section{Results and discussion \\ Characteristics analysis $X R D$ analysis}

As presented in Fig. 1, the XRD analysis of different Fe content modified biochar and PB. PB does not have any obvious and regular diffraction peaks, meaning that it is
PB amorphous. After modification with Fe, the materials exhibit obvious characteristics peaks, because of the crystalline $\mathrm{Fe}$ species of hematite $\left(\mathrm{Fe}_{2} \mathrm{O}_{3}\right)$ and magnetite $\left(\mathrm{Fe}_{3} \mathrm{O}_{4}\right)$. This shows that the $\mathrm{Fe}$ is successfully loaded into the biochar. The characteristic peak intensity of the $\mathrm{Mn}$ modified biochar, $1 \mathrm{Fe} y \mathrm{MnC}$, changes slightly from $x \mathrm{FeC}$ biochar with the increasing $\mathrm{Mn}$ content of the $1 \mathrm{Fe} y \mathrm{MnC}$ biochar. This shows that the $\mathrm{Mn}$ is successfully added to the biochar after $\mathrm{Mn}$ modification. Figure 1a showed the $1 \mathrm{FeC}$ material has the strongest $\mathrm{Fe}$ crystal peak, and the increase of $\mathrm{Fe}$ content does not change the peak. Therefore, the best ratio of Fe and carbon is $1: 1$. In addition, the optimal ratio of $\mathrm{Fe} / \mathrm{Mn} / \mathrm{C}$ is 1:2:1, and the increase of Mn content leads to the decrease of Mn crystal peak (Fig. 1b). Therefore, the 1FeC and $1 \mathrm{Fe} 2 \mathrm{MnC}$ were used for subsequent studies.

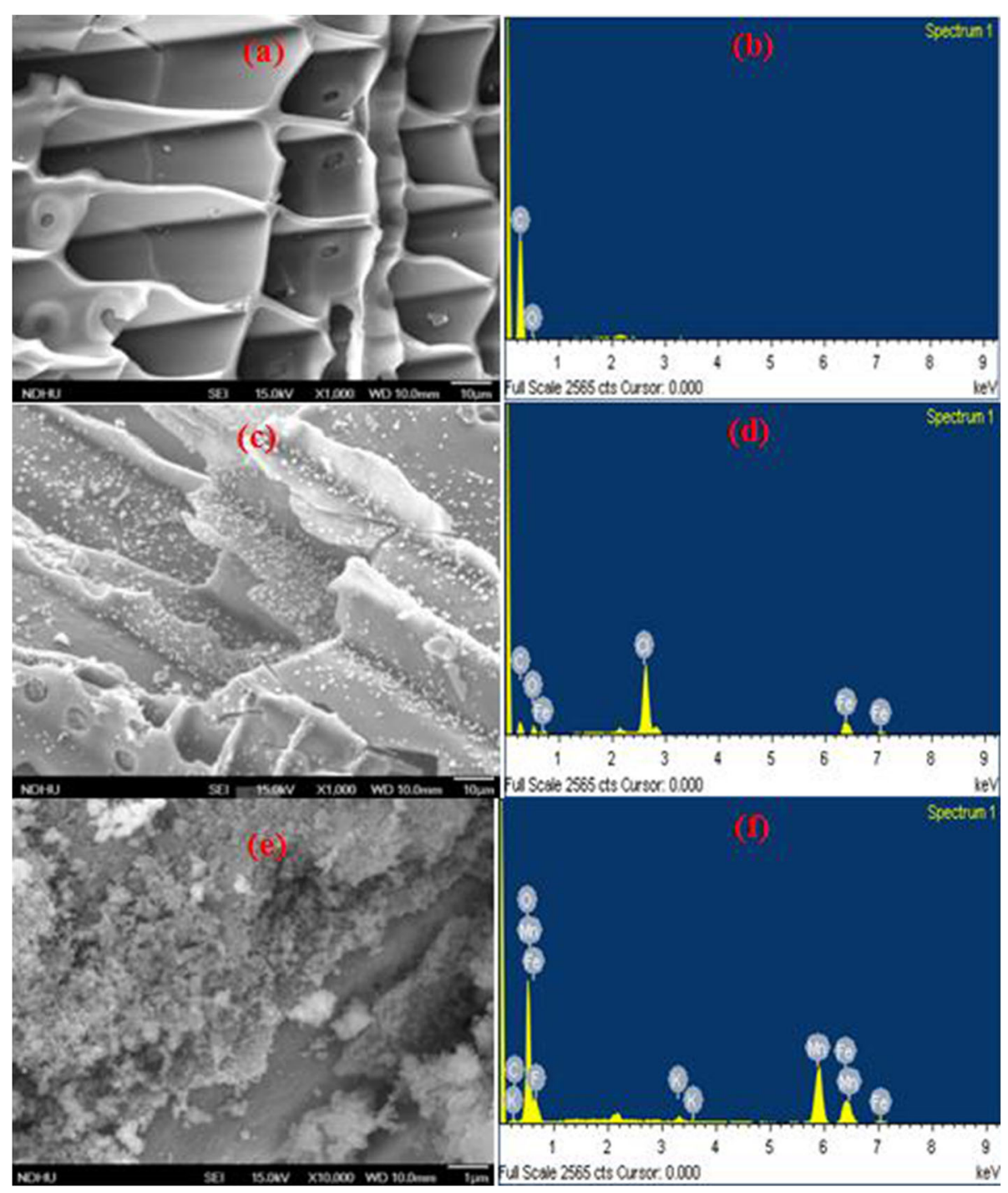

Fig. 2 SEM images and EDS analysis of a, b PB, c, d $1 \mathrm{FeC}$ and e, f $1 \mathrm{Fe} 2 \mathrm{MnC}$ 
Table 2 EDS analysis results

\begin{tabular}{lllllll}
\hline Material & \multicolumn{7}{l}{ Content of elements by weight (\%) } \\
\cline { 2 - 7 } & $\mathbf{C}$ & $\mathbf{0}$ & $\mathrm{Fe}$ & $\mathbf{M n}$ & $\mathbf{K}$ & Total \\
\hline PB & 89.6 & 10.4 & 0.00 & 0.00 & 0.00 & 100 \\
1FeC & 61.3 & 18.4 & 20.3 & 0.00 & 0.00 & 100 \\
1 Fe2MnC & 57.1 & 14.1 & 14.2 & 13.5 & 1.1 & 100 \\
\hline
\end{tabular}

\section{SEM and EDS analysis}

To obtain the typical surface morphologies and element message, SEM and EDS analysis are performed. Figure 2a shows that the surface of the $\mathrm{PB}$ is smooth and the abundant pores are arranged regularly. The formation of pores is generated by the decomposition of lignocelluloses and lignin under high temperature. The EDS results in Table 2 and Fig. 2b reveal that the elemental composition includes $\mathrm{C}$ and $\mathrm{O}$ and is consistent with the results of the elemental analyzer. Figure $2 \mathrm{c}$ shows that the many small particles in the surface uniformly block the pores of the material, correspond to Fe particles. Given the EDS results in Fig. 2d, it is evident that the particles are Fe. In Fig. 2e, a layer of dense particles emerges on the surface, decreasing the pore amounts and causing the roughness. The EDS results in Fig. $2 \mathrm{f}$ reveal that the covering particles are Fe and Mn, which is consistent with the former analysis results of XRD.

\section{The hysteresis regression analysis}

Considering the recycling of biochar after adsorption through the magnetic field, the magnetization strength is tested. Figure 3a shows that the PB has almost no magnetism. However, the modification of $\mathrm{Fe}$ increases the magnetism of materials in contrast to $\mathrm{PB}$ because of the formation of $\mathrm{Fe}_{3} \mathrm{O}_{4}$. The $0.5 \mathrm{FeC}$ can reach its highest largest magnetism levels, $5.3 \mathrm{emu} \mathrm{g}^{-1}$. However, this remains insufficient to recycle the biochar. Hence, the Mn is used to enhance the material's magnetism. Figure 3b shows that the Mn modified biochar has much higher magnetism due to the interaction between $\mathrm{Fe}$ and $\mathrm{Mn}$, which enhances its recycling ability. The highest obtained magnetization strength is $43 \mathrm{emu} \mathrm{g}^{-1}$. Son et al. [33] found that the saturation magnetization value of iron modified biochar is $8.64 \mathrm{emu} \mathrm{g}^{-1}$. This is sufficiently ferromagnetic to recollect the used biochar from the suspended solution via the external magnetic field. In this study, the $1 \mathrm{Fe} 1 \mathrm{MnC}$ and $1 \mathrm{Fe} 2 \mathrm{MnC}$ can be readily obtained by the external magnetic field with the respective saturation magnetization values of 43 and $21 \mathrm{emu}$ $\mathrm{g}^{-1}$.

\section{BET analysis}

To obtain the pore size distribution and surface area of different biochars, a BET analyzer was used before and after modification. Figure 4 shows the pore size distribution of $\mathrm{PB}, 1 \mathrm{FeC}$ and $1 \mathrm{Fe} 2 \mathrm{MnC}$ is $20.9,21.7$ and $46.4 \AA$, respectively. Table 3 show the specific surface area of $\mathrm{PB}, 1 \mathrm{FeC}$ and $1 \mathrm{Fe} 2 \mathrm{MnC}$ is 524,181 and $135 \mathrm{~m}^{2} \mathrm{~g}^{-1}$, respectively. The specific surface area decreases after modification due to the $\mathrm{Fe}$ and Mn blocking. The results are in good agreement with the SEM analysis. The mean pore size of $\mathrm{PB}, 1 \mathrm{FeC}$ and $1 \mathrm{Fe} 2 \mathrm{MnC}$ is $20.9,21.7$ and

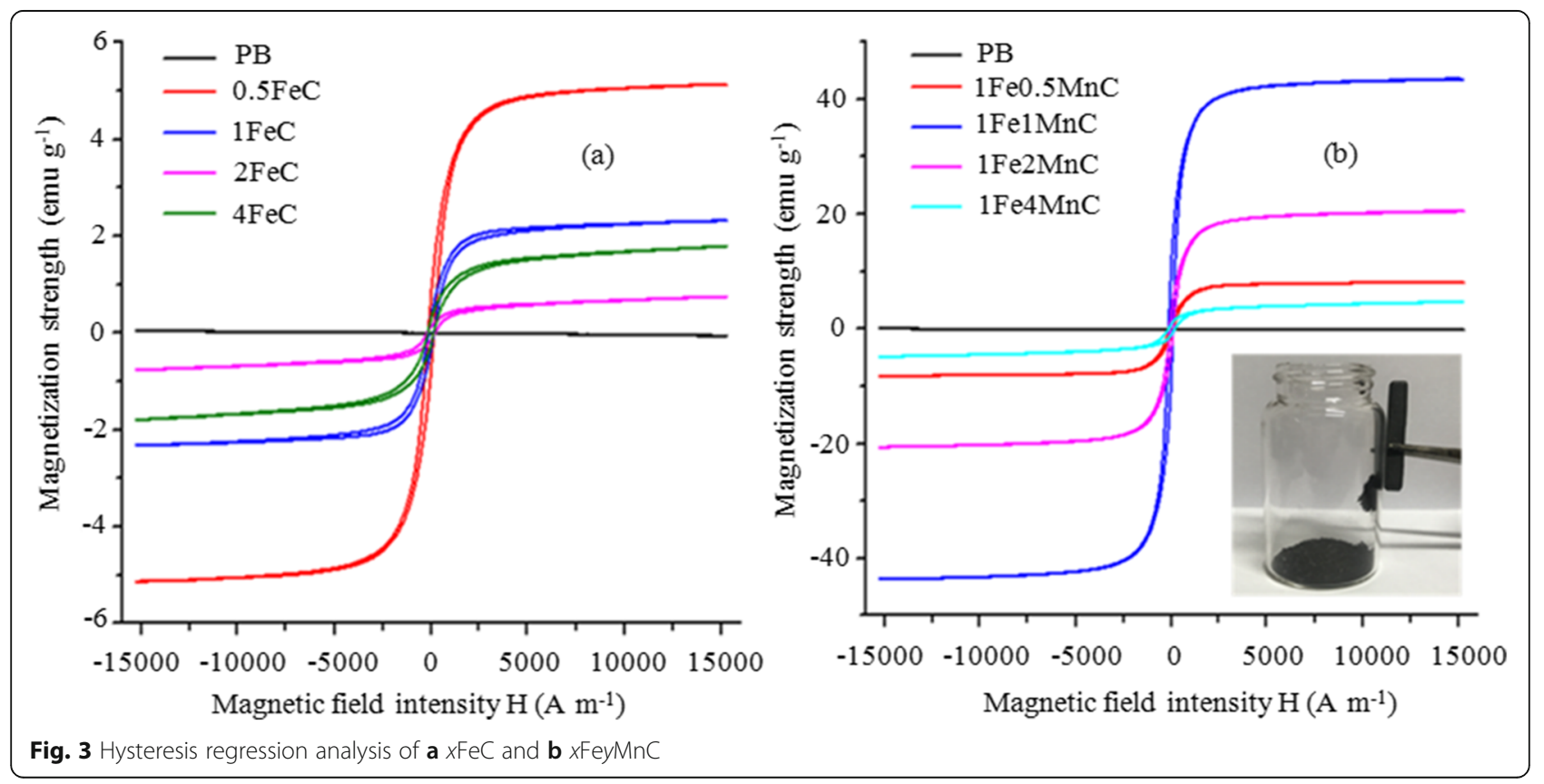



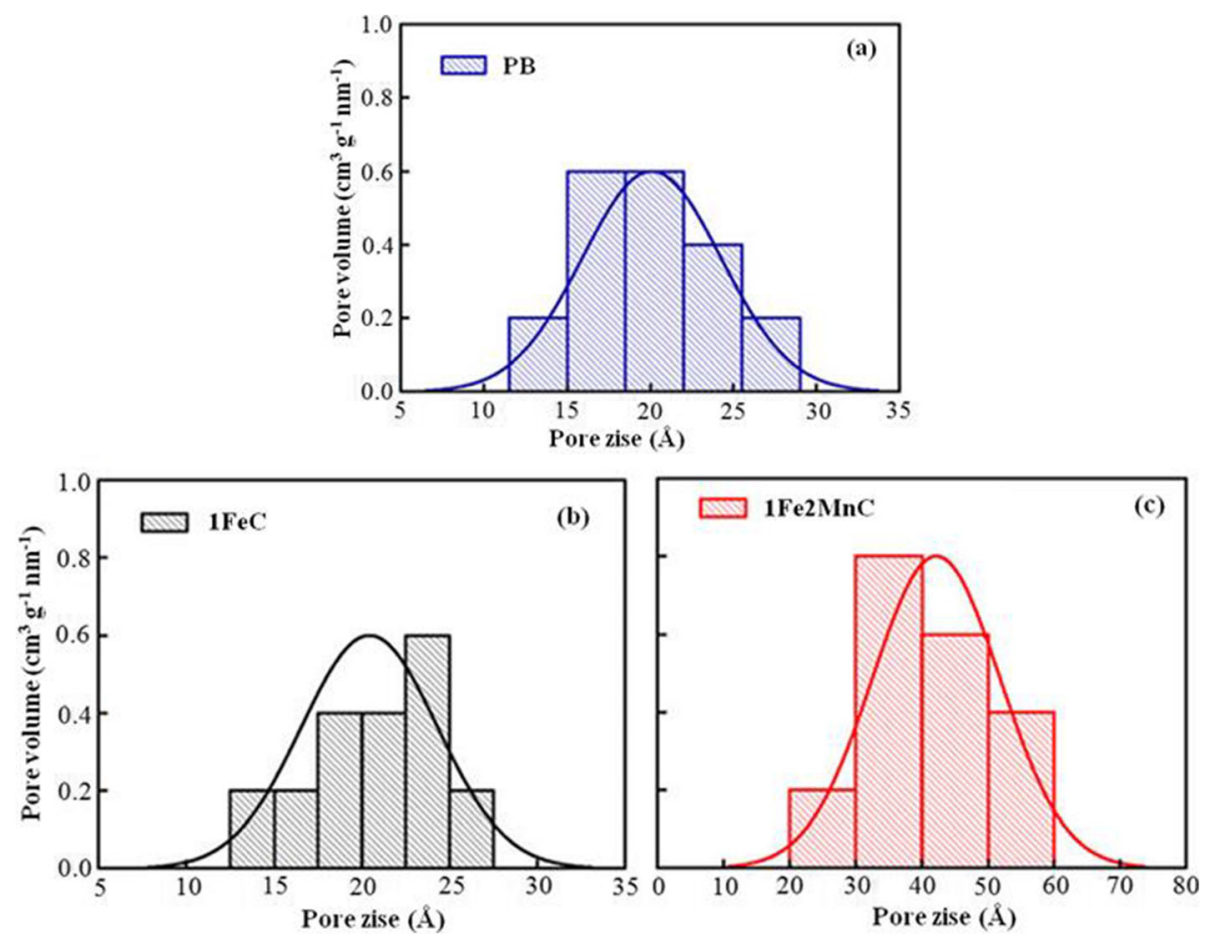

Fig. 4 The pore size distribution of a PB, b $1 \mathrm{FeC}$ and $\mathbf{c} 1 \mathrm{Fe} 2 \mathrm{MnC}$

$46.3 \AA$, respectively. They are thus mesoporous materials on the basis of the pore size between 2 and $50 \mathrm{~nm}$, while the pore size of $1 \mathrm{Fe} 2 \mathrm{MnC}$ is larger than that of the $\mathrm{PB}$ and $1 \mathrm{FeC}$ since many original small pores of $\mathrm{PB}$ are missing owing to its heavier blocking with metals and metal contents of biochar. Additionally, $\mathrm{Fe}$ and $\mathrm{Mn}$ cover on the surface of biochar and combine to form a new structure, causing the pore size of $1 \mathrm{Fe} 2 \mathrm{MnC}$ to become larger than that of the PB.

\section{FTIR analysis}

The changes in the functional groups of biochars before and after modification were analyzed by FTIR spectroscopy, as shown in Fig. 5. The - $\mathrm{OH}$ and $\mathrm{N}-\mathrm{H}$ stretching vibration band are characteristic peaks of the amine group at about $3400 \mathrm{~cm}^{-1}$ [34]. The appearance of peaks at 2930 and $2849 \mathrm{~cm}^{-1}$ in the spectrum were attributed to $\mathrm{C}-\mathrm{H}$ stretching vibration in $-\mathrm{CH}$ and $-\mathrm{CH}_{2}$ [34]. $\mathrm{C}=\mathrm{O}$ vibrations at $1750 \mathrm{~cm}^{-1}$ are produced by the stretching vibration of the oxygen-containing functional group $\mathrm{C}=$ $\mathrm{O}$ bond [35]. The band at $1620 \mathrm{~cm}^{-1}$ can be ascribed to $\mathrm{C}=\mathrm{C}$ aromatic ring stretching vibration [35]. The band at $1470-1430 \mathrm{~cm}^{-1}$ is ascribed to $\mathrm{C}-\mathrm{H}$ bending vibrations in $\mathrm{CH}_{3}$ groups [34]. The nature of the feedstock was reflected by the presence of bands around 1040$1100 \mathrm{~cm}^{-1}$, which were assigned to $\mathrm{SiO}_{2}$, and these bands were observed in all biochar carbon [36].

\section{Performance test analysis}

The influence of modification for biochar

Figure 6a shows that the As (III) removal efficiency of the Fe modified biochar was greater than that of the PB. These results are consistent with the experimental results of Kim et al. [37]. The highest removal efficiency with $\mathrm{Fe}$ modified biochar was $62 \%$, almost 5 times that of $\mathrm{PB}$, owing to the formation of $\mathrm{R}-\mathrm{FeH}_{2} \mathrm{AsO}_{3}, \mathrm{R}$ $\mathrm{FeHAsO}_{3}{ }^{-}, \mathrm{R}-\mathrm{FeAsO}_{3}{ }^{2-}, \mathrm{R}_{-} \mathrm{Fe}_{2} \mathrm{HAsO}_{3}$ and $\mathrm{R}-\mathrm{Fe}_{2} \mathrm{AsO}_{3}{ }^{-}$ species, where $\mathrm{R}$ identifies functional group of the biochar. The ligand exchange between the arsenite anion and the hydroxyl functional group of Fe oxide in the Femodified adsorbents can increase the interaction of As (III) and biochar. With the increasing Fe, the efficiency first increases, but decreases thereafter. The reason for the eventual decrease may be Fe blocking of the pore structure, which can directly decrease the specific surface area. Figure $6 \mathrm{~b}$ clearly shows that the Mn modification has a significant effect on the removal ability. The highest efficiency is $81 \%$ with $1 \mathrm{Fe} 2 \mathrm{MnC}$, which is seven

Table 3 Analysis data of surface area and pore size

\begin{tabular}{|c|c|c|}
\hline Materials & Surface area $\left(\mathrm{m}^{2} \mathrm{~g}^{-1}\right)$ & Pore size $(\AA)$ \\
\hline$\overline{\mathrm{PB}}$ & 524 & 20.9 \\
\hline $1 \mathrm{FeC}$ & 181 & 21.7 \\
\hline 1Fe2MnC & 135 & 46.3 \\
\hline
\end{tabular}




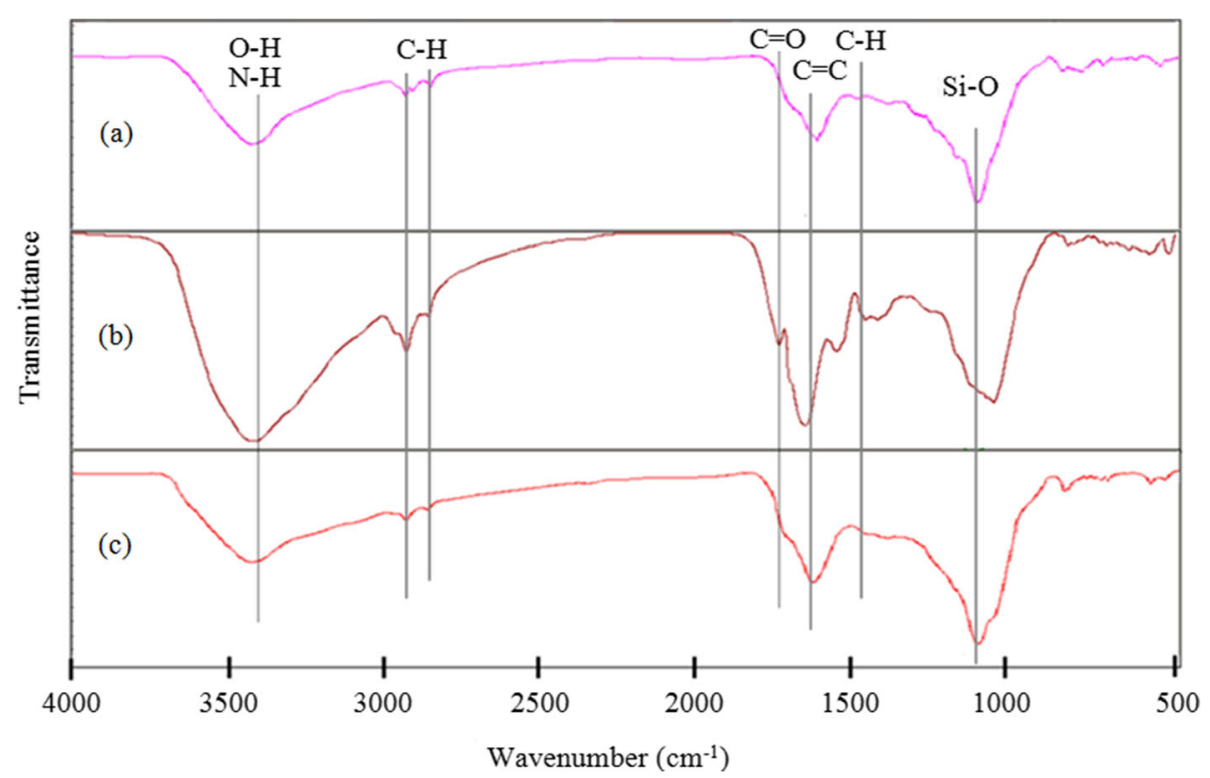

Fig. 5 FTIR spectrums of a PB, b $1 \mathrm{Fe} 2 \mathrm{MnC}$ and $\mathbf{c} 1 \mathrm{FeC}$

times higher than that of the PB. This may be due to the oxidation of As (III) to As(V) when Mn added. Similar observations of the redox potential of $\mathrm{Mn}$ have been found by Lin et al. [26]. Apart from this, the reduction products of $\mathrm{Mn}^{3+}$ to $\mathrm{Mn}^{2+}$ can play a role similar to that of Fe ions as noted above. Additionally, the variations in $\mathrm{pH}$ value were not obvious before and after the adsorption experiment.

\section{The influence of $\mathrm{pH}$}

The effect of the As removal was studied by varying the $\mathrm{pH}$ values over the 3.0-11.0 range. To study the electrostatic force between As (III) and adsorbents, a zeta potential experiment of the three types biochar was studied and the results shown in Fig. 7a. The $\mathrm{pH}$ at zeta potential is $4.2,6.1$ and 2.1 for the $\mathrm{PB}, 1 \mathrm{FeC}$ and $1 \mathrm{Fe} 2 \mathrm{MnC}$, respectively. This can help identify the surface charge of
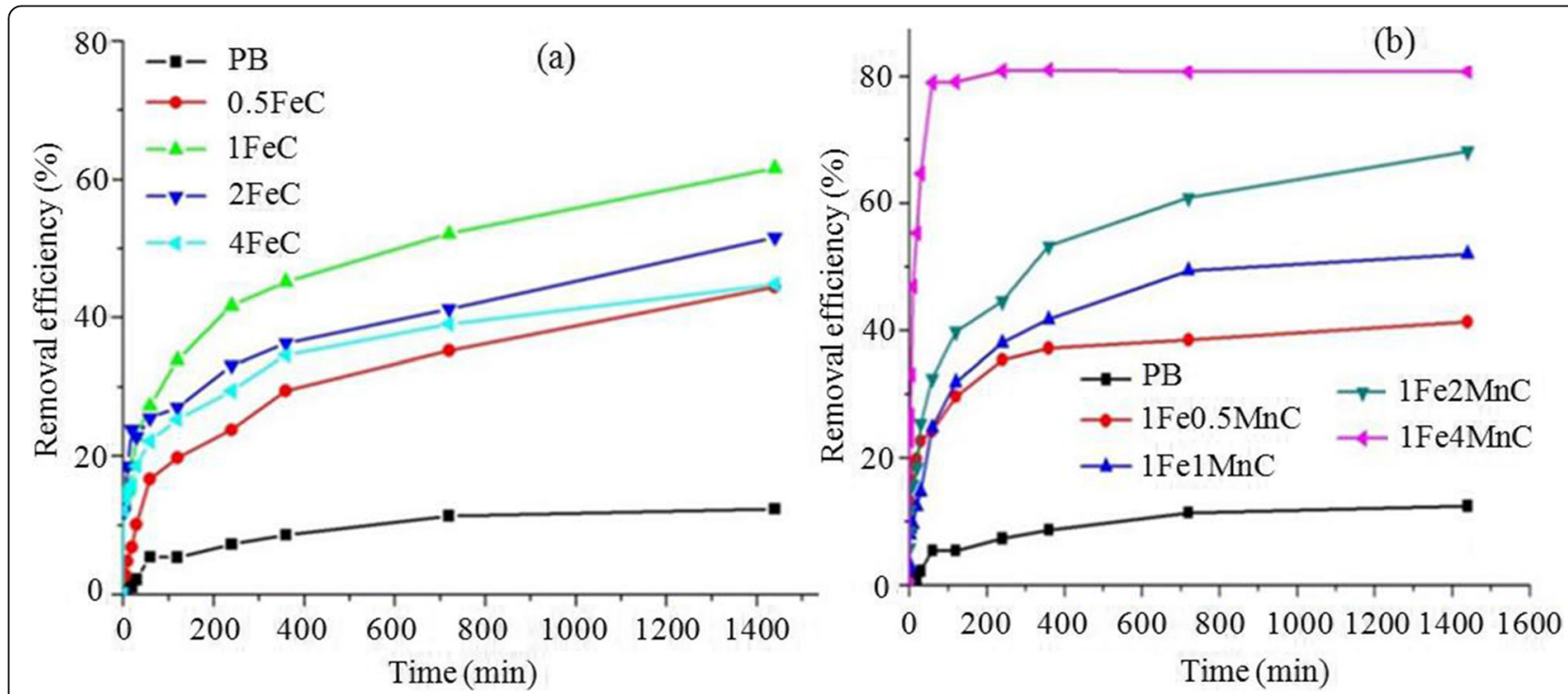

Fig. $\mathbf{6}$ As removal efficiency with $\mathbf{a} \times \mathrm{FeC}$ and $\mathbf{b} \times \mathrm{FeyMnC}$ 

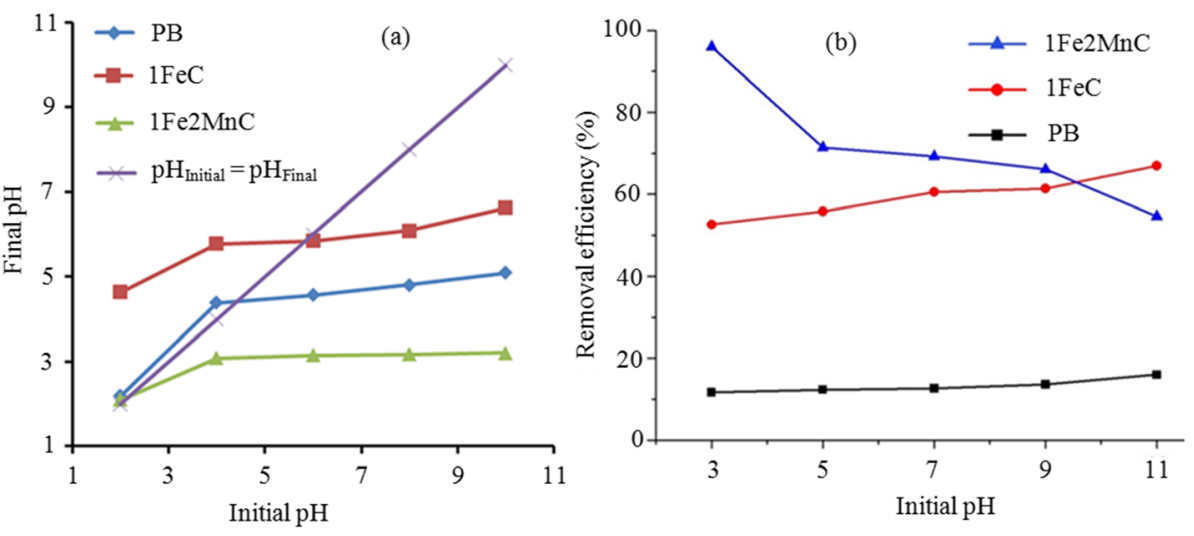

Fig. 7 a Zeta potentials and $\mathbf{b}$ effects of initial pH on the As (III) removal efficiency

the adsorbents. When the solution $\mathrm{pH}$ is below the zeta potential $\mathrm{pH}$, the surface is positively charged, and viceversa. As presented in Fig. $7 \mathrm{~b}$, the $\mathrm{pH}$ exhibits different effects on the removal efficiency of the three types of biochar, which may relate to the reaction mechanism. The PB shows negligible influence. By contrast, the efficiency with $1 \mathrm{FeC}$ increases with slightly increasing $\mathrm{pH}$. The adsorption efficiency with $1 \mathrm{Fe} 2 \mathrm{MnC}$ clearly decreases with increasing $\mathrm{pH}$.

The rise in As (III) removal efficiency may be due to chemical adsorption rather than electrostatic attraction at high $\mathrm{pH}$ value, such as $\mathrm{pH} 9 . \mathrm{H}_{3} \mathrm{AsO}_{3}{ }^{\circ}$ and $\mathrm{H}_{2} \mathrm{AsO}_{3}{ }^{-}$ could connect with deprotonated $\mathrm{Fe}-\mathrm{O}$ surface sites through the hydrogen-bond at higher $\mathrm{pH}$ prior to chemical adsorption [38]. The $1 \mathrm{Fe} 2 \mathrm{MnC}$ has the highest removal efficiency at a low $\mathrm{pH}$, around 3. Compared to other adsorption forces, the electrostatic attraction is dominant. The zeta potential of the $1 \mathrm{Fe} 2 \mathrm{MnC}$ is around 2.0 and the As (III) exists as almost a negative species in the experimental range. Above $\mathrm{pH} 3$, the biochar surface is much more negative. Therefore, electrostatic repulsion will reduce the As (III) uptake heavily. Sattar et al. [39] have shown As (III) adsorption reaching at maximum adsorption at 7.1 and 7.2 near-neutral $\mathrm{pH}$ by biochar.

\section{The influence of initial concentration}

The three lines reveal that the removal capacity increases from 0.056 to 0.16 , from 0.17 to 0.89 and from

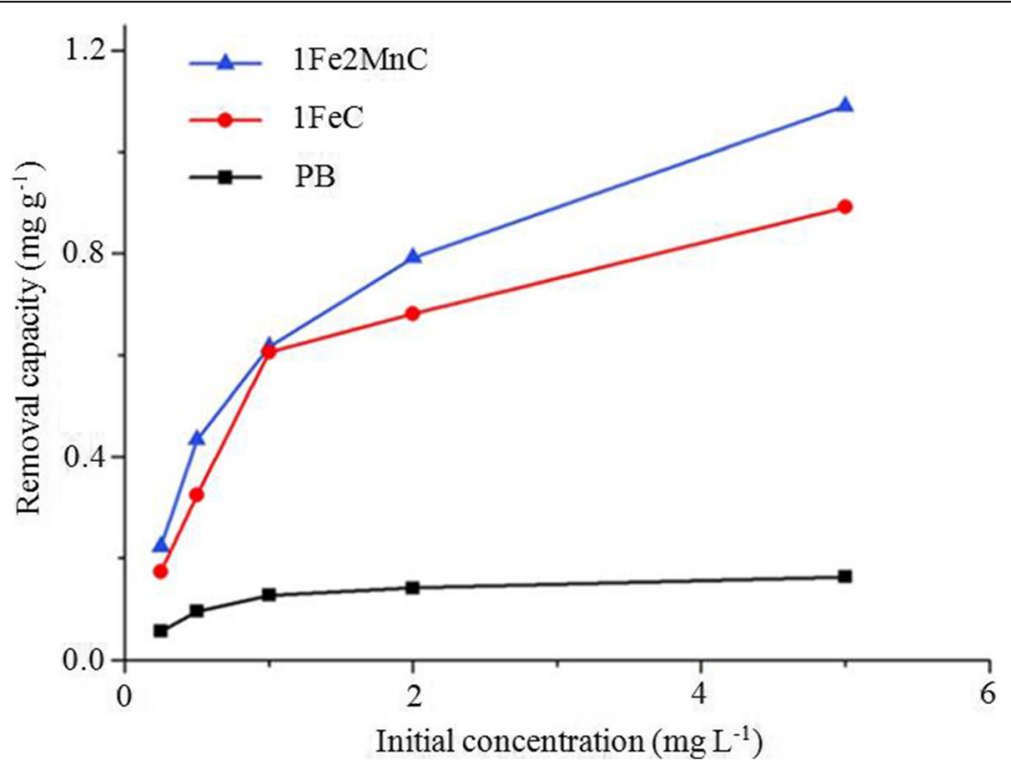

Fig. 8 The influence of initial concentration of As (III) 


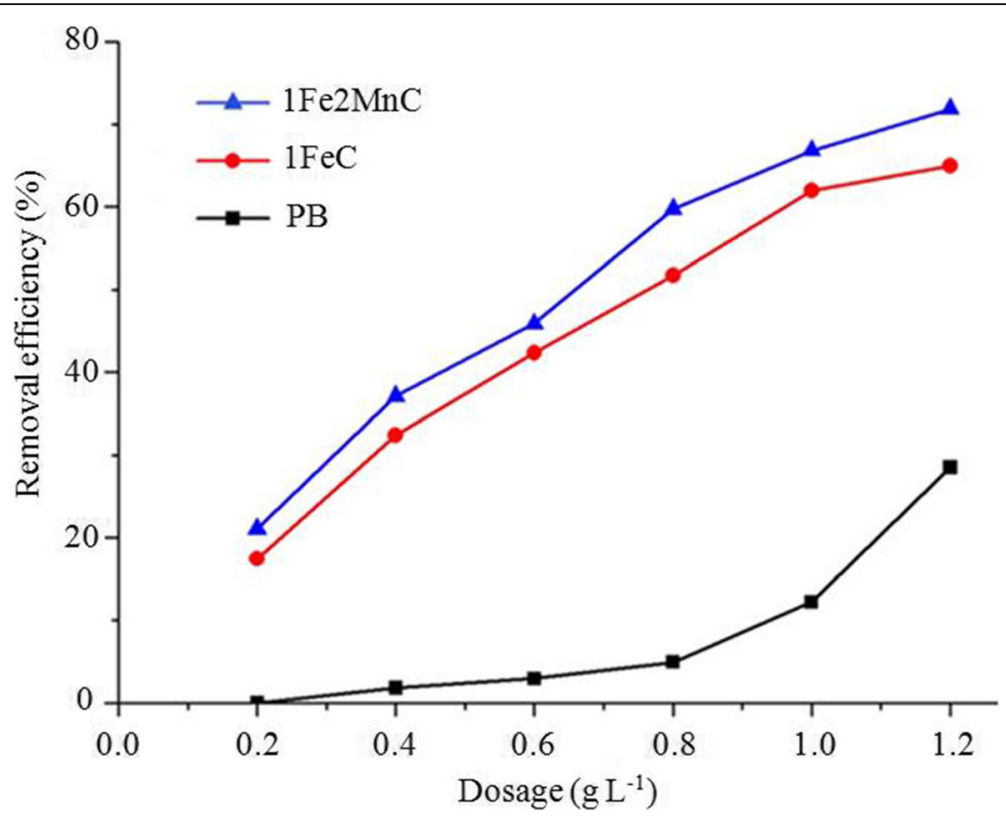

Fig. 9 The influence of adsorbents dosage

0.22 to $1.1 \mathrm{mg} \mathrm{g}^{-1}$, respectively, with an increase in the initial As (III) concentration from 0.25 to $5.0 \mathrm{ppm}$. Prior to the saturation of active sites present on the adsorbent surface and the higher concentration of As, more active sites can be used. Hence, the value of $q_{e}$ can greatly increase. However, the $q_{e}$ of PB stopped increasing after 2 ppm mainly due to the saturation occurring earlier than with the modified biochar. By contrast, the increasing trend with the modified biochar reveals a higher removal potential than the unmodified biochar, as show in Fig. 8.

\section{The influence of dosage}

As shown in Fig. 9, six different dosages (0.2, 0.4, 0.6, $0.8,1.0$ and $1.2 \mathrm{~g} \mathrm{~L}^{-1}$ ) of $\mathrm{PB}, 1 \mathrm{FeC}$ and $1 \mathrm{Fe} 2 \mathrm{MnC}$ have

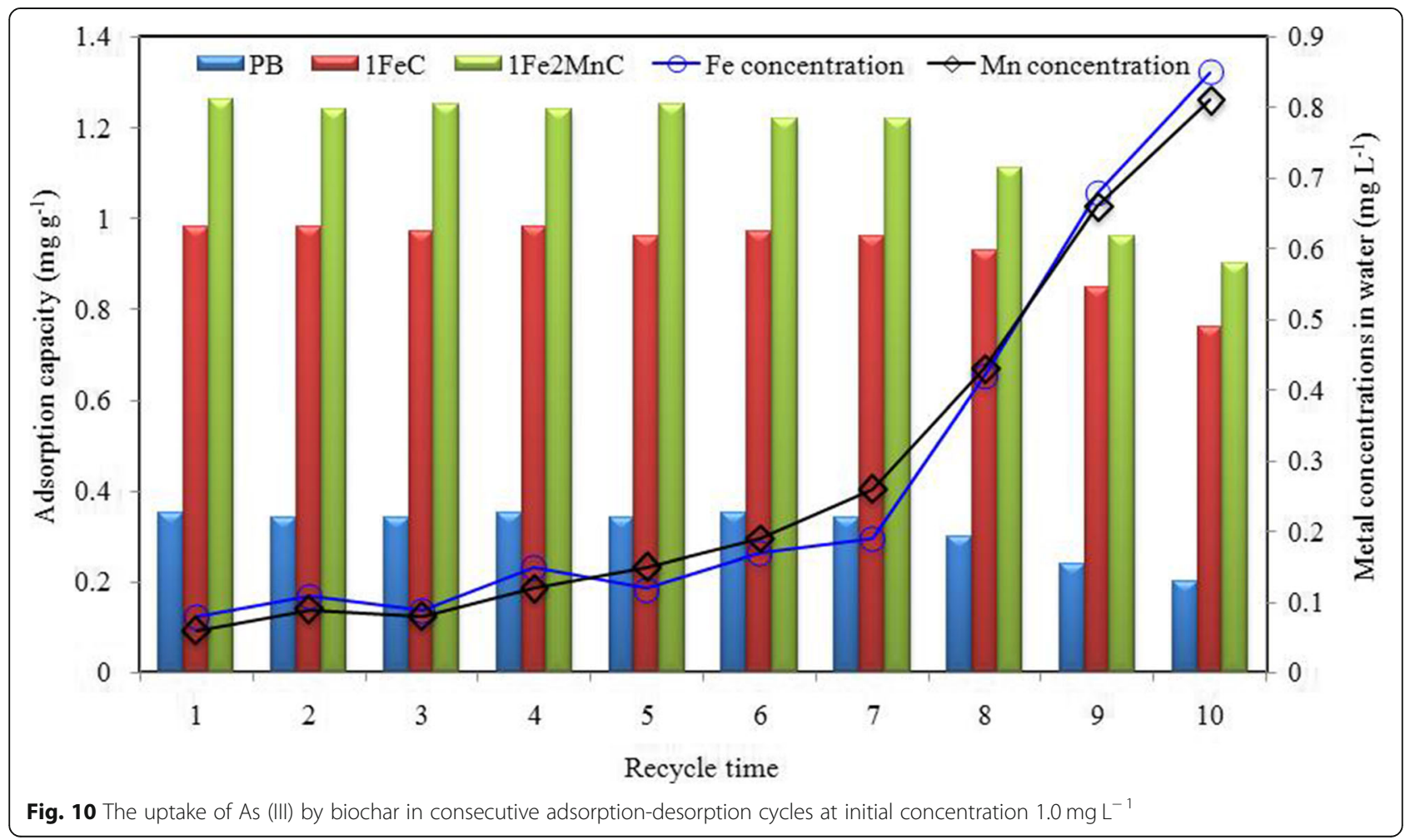


Table 4 Parameters for different isotherm of As (III) adsorption with biochars

\begin{tabular}{lllll}
\hline Model & Parameters & PB & 1FeC & 1Fe2MnC \\
\hline Langmuir & $b\left(\mathrm{mg} \mathrm{g}^{-1}\right)$ & 0.18 & 1.0 & 0.90 \\
& $a\left(\mathrm{~L} \mathrm{mg}^{-1}\right)$ & 2.32 & 2.73 & 12.5 \\
\multirow{5}{*}{ Freundlich } & $\mathrm{R}^{2}$ & 0.990 & 0.992 & 0.980 \\
& $K\left(\mathrm{mg} \mathrm{g}^{-1}\right)$ & 0.11 & 0.61 & 1.30 \\
& $n$ & 3.19 & 2.57 & 3.46 \\
\multirow{5}{*}{ Temkin } & $\mathrm{R}^{2}$ & 0.874 & 0.871 & 0.940 \\
& $B\left(\mathrm{~J} \mathrm{~mol}^{-1}\right)$ & 30 & 180 & 160 \\
& $K_{T}\left(\mathrm{~J} \mathrm{~g}^{-1}\right)$ & 40 & 42 & 159 \\
& $\mathrm{R}^{2}$ & 0.953 & 0.955 & 0.975 \\
\hline
\end{tabular}

been tested. The maximum removal efficiency of $72 \%$ is found at the dosage of $1.2 \mathrm{~g} \mathrm{~L}^{-1}$. The more adsorbents used, the more active sites can be supported. Therefore, more As (III) can be removed as the number of active sites increases. In addition, the removal efficiency increased in the range of $0.0-29 \%, 17-65 \%$ and $21-72 \%$, respectively, under the studied dosages from 0.2 to $1.2 \mathrm{~g}$ $\mathrm{L}^{-1}$. By contrast, the measurement of $q_{e}$ shows the opposite results because of the diminution of equivalent active functional sites on the surface of the adsorbents.
The decrease in adsorption capacity is due to the increase in intermolecular attraction between the adsorbent.

\section{Effects of recycle times}

The adsorption capacity of As (III) on PB, 1FeC and $1 \mathrm{Fe} 2 \mathrm{MnC}$ is not substantially changed after seven recycles of the adsorption-desorption processes, as shown in Fig. 10. Most of the adsorbed As (III) species can be desorbed from biochar by the alkaline at $\mathrm{pH} 11.5$, which is in good accordance with the previous results on the effect of $\mathrm{pH}$ on As (III) species adsorption. However, after seven recycles of the adsorption-desorption processes, the adsorption capacity of the As (III) on biochar exhibited an obvious decline. It is possible that the structure of the $1 \mathrm{FeC}$ and $1 \mathrm{Fe} 2 \mathrm{MnC}$ begins to be damaged and the metal element is detached. Therefore, the turbidity of the solution along with the metal concentration is increased significantly after seven recycles.

\section{Adsorption isotherm models analysis}

Foo and Hameed [40] explained that the analysis of adsorption isotherms models can be used for investigating the adsorption behavior and assessing the feasibility of field application. To obtain the three types of biochar

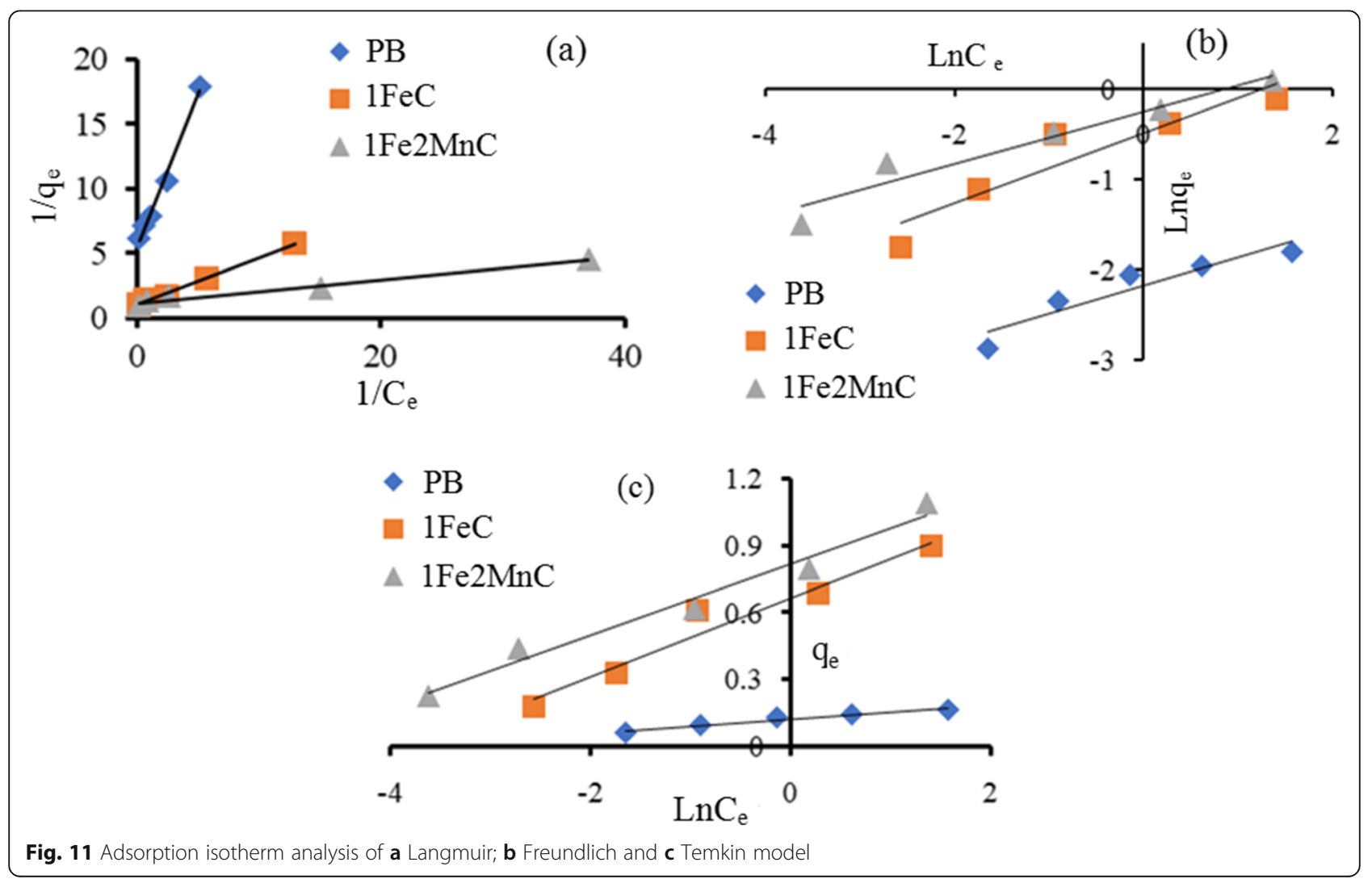


Table 5 The adsorption dynamics parameters of different models

\begin{tabular}{lllll}
\hline Adsorption model & & PB & 1FeC & 1Fe2MnC \\
\hline Pseudo-first-order & $k_{1}\left(\mathrm{~min}^{-1}\right)$ & 0.003 & 0.002 & 0.003 \\
& $q_{\text {maxdy }}\left(\mathrm{mg} \mathrm{g}^{-1}\right)$ & 0.12 & 0.50 & 0.48 \\
& $\mathrm{R}^{2}$ & 0.980 & 0.919 & 0.938 \\
Pseudo-second-order & $k_{2}\left(\mathrm{mg} \mathrm{g}^{-1} \mathrm{~min}^{-1}\right)$ & 0.056 & 0.029 & 0.031 \\
& $q_{\text {maxdy }}\left(\mathrm{mg} \mathrm{g}^{-1}\right)$ & 0.14 & 0.67 & 0.62 \\
& $\mathrm{R}^{2}$ & 0.981 & 0.986 & 0.991 \\
\hline
\end{tabular}

surface properties and the behaviors in adsorbing As (III), commonly used adsorption isotherm models, such as Langmuir, Freundlich and Temkin, are applied here in to fit the experimental data in the present study. The Langmuir adsorption isotherm model is based on the assumption that the entire adsorption process is a singlemolecule layer adsorption between the solute and solid phases, while the Freundlich adsorption isotherm model is an empirical equation without assumptions and without considering adsorption saturation. The multimolecular layer adsorption process occurring on an uneven surface is simulated. The Freundlich model is based on the hypothesis that the binding sites are not equal and there is a heterogeneous surface for adsorption [41]. The Temkin equation is used to describe the adsorption equilibrium of a single molecular layer in a non-ideal adsorption system.

The experiments are operated for the concentrations of $0.25,0.5,1.0,2.0$ and $5.0 \mathrm{mg} \mathrm{L}^{-1}$, respectively. Compared to the other models, our results better fit the Langmuir model with the linear correlation coefficients $\left(\mathrm{R}^{2}\right)$ of $0.990,0.992$ and 0.980 . These results reveal that the adsorption is a single molecule adsorption. In addition, the maximum adsorption capacity based on the simulation of the Langmuir model is $0.18,1.0$ and 0.90 $\mathrm{mg} \mathrm{g}^{-1}$ for $\mathrm{PB}, 1 \mathrm{FeC}$ and $1 \mathrm{Fe} 2 \mathrm{MnC}$, respectively. For the constant value $n$ for the Freundlich adsorption isotherm model, the values are 3.19, 2.57 and 3.46, respectively, all in the range of 2 to 10. Prepared biochars are thus unfavorable for As (III) adsorption. According to the value $B$ of Temkin model with larger than $20 \mathrm{~J} \mathrm{~mol}^{-1}$, the adsorption energies for typical chemical adsorption. In this research, the value of $B$ is 30,180 and $160 \mathrm{~J} \mathrm{~mol}^{-1}$, indicating that the adsorption process involves chemical adsorption, as shown in Table 4 and Fig. 11.

\section{Adsorption dynamics}

Adsorption of As (III) in wastewater by the adsorbent is a complicated adsorption reaction process. To explore the speed of the three different types of biochar to adsorb As (III), the kinetic adsorption models are tested to obtain the related constants. In this research, the pseudo-first-order and pseudo-second-order are simulated and the relevant kinetic parameters $k_{1}, k_{2}, q_{\max d y}$ (maximum adsorption capacity of dynamic simulation) and $R^{2}$ are presented in Table 5 and Fig. 12 .

The three types of biochar fit the pseudo-second-order simulation better under the consideration of both the $\mathrm{R}^{2}$ and $q_{e}$ value. The $\mathrm{R}^{2}$ of pseudo-second-order simulation is $0.981,0.986$ and 0.991 , respectively, and the value is $0.980,0.919$ and 0.938 for the pseudo-first-order simulation. Table 5 shows that the modified biochar reveals much stronger adsorption ability towards As (III). The saturated adsorption capacity of the three types of biochar is $0.14,0.67$ and $0.62 \mathrm{mg} \mathrm{g}^{-1}$, respectively, with $\mathrm{PB}$, $1 \mathrm{FeC}$ and $1 \mathrm{Fe} 2 \mathrm{MnC}$ under the simulation of pseudosecond-order simulation at $\mathrm{pH} 7$ and $298 \mathrm{~K}$. This is much closer to the specific experimental data of 0.13 ,

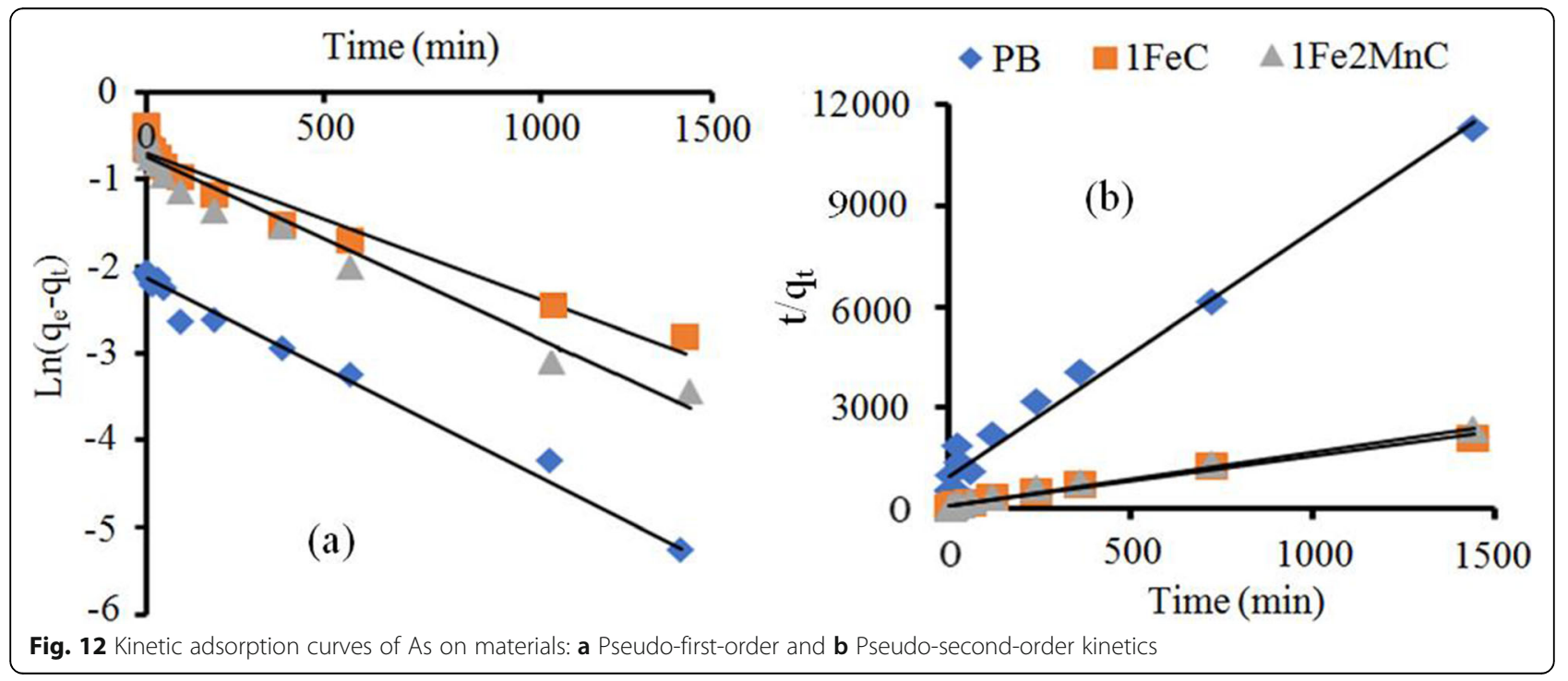


0.68 and $0.62 \mathrm{mg} \mathrm{g}^{-1}$, respectively, than with the values of $0.12,0.50$ and $0.48 \mathrm{mg} \mathrm{g}^{-1}$ obtained from pseudofirst-order simulation. In addition, the adsorption capacity of the three types of biochar towards As (III) follows the ranks order as $1 \mathrm{FeC}>1 \mathrm{Fe} 2 \mathrm{MnC}>\mathrm{PB}$. This simulation trend is corresponding with the actual experiment data in the given situation of $\mathrm{pH} 7$ and $298 \mathrm{~K}$.

\section{Thermodynamics analysis}

Thermodynamic parameters were determined from Eqs. (12) and (13), respectively. The plot of $\ln K_{L}$ as a function of $1 / T$ yields a straight line $\left(\mathrm{R}^{2}=0.947\right)$ from which $\Delta H^{\circ}$ and $\Delta S^{\circ}$ were calculated from the slope and intercept, respectively. The negative values of $\Delta G^{o}(-1.42,-4.56$, -8.93 and $-9.88 \mathrm{~kJ} \mathrm{~mol}^{-1}$ at 288, 298, 308 and $318 \mathrm{~K}$, respectively) suggested that the adsorption process was spontaneous. However, the increase in absolute values of $\Delta G^{o}$ with increasing temperature shows an increase in feasibility of adsorption at higher temperatures. In addition, the negative values of $\Delta G^{o}$ in this study were within the ranges of -20 and $0 \mathrm{~kJ} \mathrm{~mol}^{-1}$, which indicated that the adsorption mechanism was mainly a spontaneous reaction [42]. The positive value of $\Delta H^{o}(84.8 \mathrm{~kJ}$ $\mathrm{mol}^{-1}$ ) indicates the endothermic nature of the adsorption processes. The positive $\Delta H^{o}$ is an indicator of endothermic nature of the adsorption process and also its magnitude gives information on the type of adsorption, which can be either physical or chemical. The enthalpy of adsorption, ranging from 2.1 to $20.9 \mathrm{~kJ} \mathrm{~mol}^{-1}$
Table 6 Thermodynamic model parameter values at different temperatures with $1 \mathrm{Fe} 2 \mathrm{MnC}$

\begin{tabular}{llll}
\hline Temperature (K) & $\Delta \boldsymbol{G}^{\mathbf{o}}\left(\mathrm{kJ} \mathrm{mol}^{-\mathbf{1}}\right)$ & $\Delta \boldsymbol{H}^{\mathbf{o}}\left(\mathbf{k J ~ m o l}^{-\mathbf{1}}\right)$ & $\Delta \boldsymbol{S}^{\mathbf{o}}\left(\mathrm{J} \mathrm{mol}^{-\mathbf{1}} \mathbf{K}^{-\mathbf{1}}\right)$ \\
\hline 288 & -1.42 & 84.8 & 302 \\
298 & -4.56 & & \\
308 & -8.93 & & \\
318 & -9.88 & & \\
\hline
\end{tabular}

corresponds to physical adsorption and higher than 20.9 $\mathrm{kJ} \mathrm{mol}^{-1}$ is chemical adsorption [43]. The $\Delta H^{o}$ value of As (III) adsorption onto $1 \mathrm{Fe} 2 \mathrm{MnC}$ is in range of chemical adsorption. Therefore, the $\Delta H^{o}$ value shows that the adsorption process was taken place via chemical adsorption. The positive value of $\Delta S^{o}\left(302 \mathrm{~J} \mathrm{~mol}^{-1} \mathrm{~K}^{-1}\right)$ showed the affinity of $1 \mathrm{Fe} 2 \mathrm{MnC}$ for As (III) and the increasing randomness at the solid-solution interface during the adsorption process, as shown in Table 6.

\section{Mechanism assumption}

Base on the results of the material property analysis and adsorption performance evaluation, possibly existence reaction models can be assumed in Fig. 13. The reaction types of the adsorption of arsenic by biochar include both physical and chemical reactions, and the As (III) was removed with major contribution by chemical reaction. Biochar can connect with arsenic through hydrogen bonding from the functional group - $\mathrm{OH}$ in biochar and the arsenic itself. Further, they can attract each other by

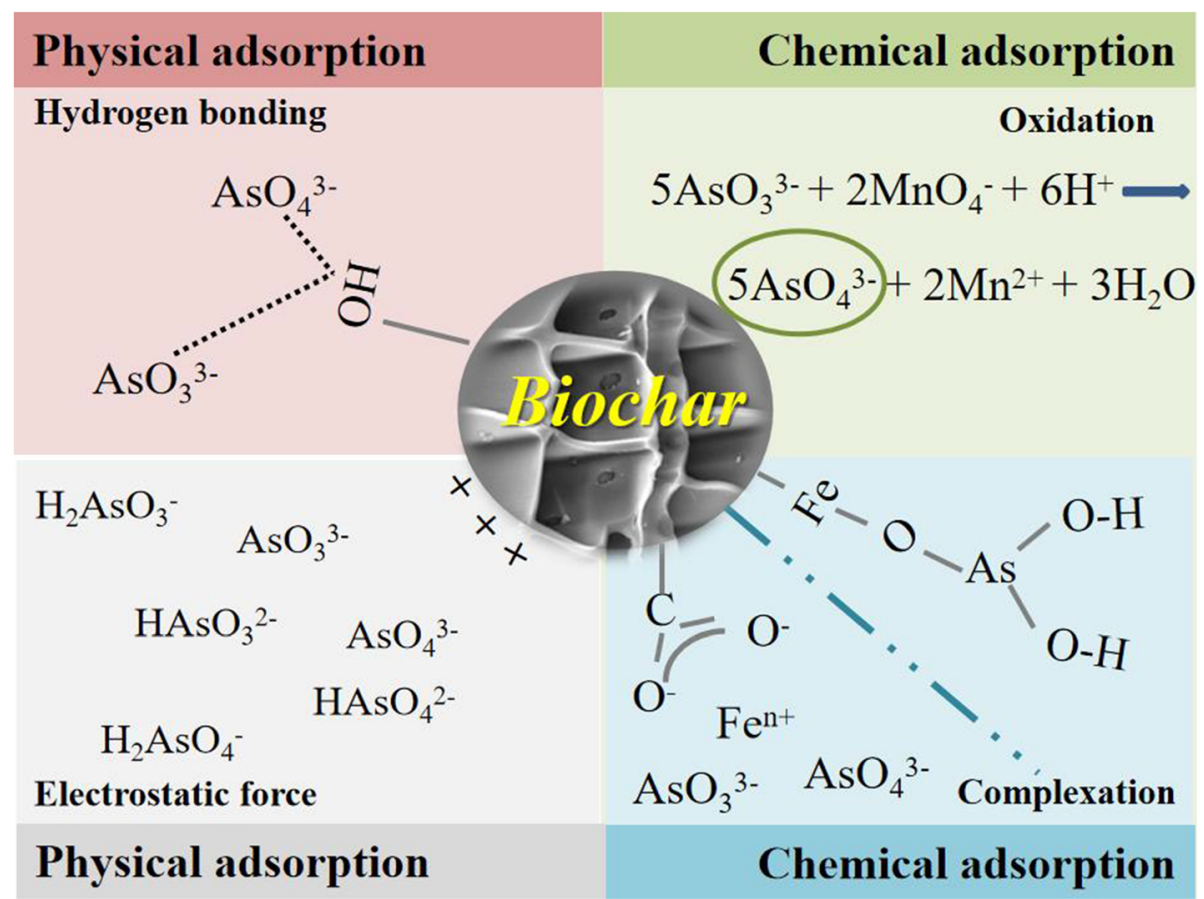

Fig. 13 Schematic diagram of reaction mechanism analysis 
electron force when the biochar surface is filled with positive charge. Compounds of manganese have strong oxidizability to oxidize As (III) to As(V) [44]. By comparison, $\mathrm{As}(\mathrm{V})$ is easier to be removed. In addition, the iron ions act as a bridge to connect the biochar and the $\mathrm{As}(\mathrm{V})$ resulting in the formation of new complex compounds.

\section{Conclusions}

XRD analysis results show that $\mathrm{Fe}_{2} \mathrm{O}_{3}$ and $\mathrm{Fe}_{3} \mathrm{O}_{4}$ occur on the surface of the $x \mathrm{FeC}$. SEM-EDS analysis results demonstrates that iron and $\mathrm{Mn}$ ions are successfully coated because the smooth surface changes to rough surface after coating and the elements of Fe and Mn appear in the EDS analysis. Hysteresis regression analysis shows that magnetism of the $x \mathrm{FeC}$ and $x \mathrm{Fe} y \mathrm{MnC}$ is increased to far more than that of the PB. $0.5 \mathrm{FeC}$ adsorbents can reach the largest magnetism, $5.3 \mathrm{emu} \mathrm{g}^{-1}$. The highest magnetization strength is $43 \mathrm{emu} \mathrm{g}^{-1}$ from the $1 \mathrm{Fe} 2 \mathrm{MnC}$. From the nitrogen absorption and desorption analysis, the specific surface areas of the $\mathrm{PB}, 1 \mathrm{FeC}$ and $1 \mathrm{Fe} 2 \mathrm{MnC}$ are 524, 181 and $135 \mathrm{~m}^{2} \mathrm{~g}^{-1}$, respectively. Further, they are all mesoporous materials, given their average pore size. The arsenic removal efficiency with $\mathrm{FeC}$ and $\mathrm{FeMnC}$ is much higher than that of the $\mathrm{PB}$ at $\mathrm{pH}$ 7. In particular, the removal efficiency with $1 \mathrm{FeC}$ and $1 \mathrm{Fe} 4 \mathrm{MnC}$ reaches 62 and $81 \%$, respectively. As $\mathrm{pH}$ increases, the removal efficiency of As (III) with PB and $1 \mathrm{FeC}$ increases slightly while it clearly decreases with 1Fe2MnC. The adsorption behaviors with $\mathrm{PB}, 1 \mathrm{FeC}$ and $1 \mathrm{Fe} 2 \mathrm{MnC}$ all fit the Langmuir isothermal adsorption model and pseudo-second-order adsorption dynamics model better. The reaction mechanisms for removing arsenic include physical and chemical reactions, including electrostatic function, oxidation reaction, complexation reaction and hydrogen bonding function.

\section{Acknowledgements}

The authors acknowledge financial supports form the Taiwan's Ministry of Science and Technology (MOST 107-2622-E-197-001-CC3). First author acknowledges the Department of Environmental Engineering, National I-Lan University, Taiwan to support his research at the university.

\section{Authors' contributions}

Chih-Kuei Chen provided real test data, Jia-Jia Chen supported the test data, Nhat-Thien Nguyen and Nguyen-Cong Nguyen wrote the paper, Thuy-Trang Le analyzed the test data, and Chang-Tang Chang organized the researched full structure. All authors read and approved the final manuscript.

\section{Funding}

Not applicable.

\section{Availability of data and materials}

All data generated or analyzed during this study are examined by our group and certified for several times.

\section{Declaration}

Competing interests

The authors declare they have no competing interests.

\section{Author details}

'Department of Environmental Engineering, National I-Lan University, I-Lan 26047, Taiwan. ${ }^{2}$ Continental Water Engineering Corporation, Taipei 10608, Taiwan. ${ }^{3}$ Institute of Environmental Engineering and Management, National Taipei University of Technology, Taipei 10608, Taiwan. ${ }^{4}$ Faculty of Environment and Chemical Engineering, Duytan University, Danang 500000, Viet Nam. ${ }^{5}$ Faculty of Chemistry and Environment, Dalat University, Dalat 66100, Viet Nam.

Received: 21 December 2020 Accepted: 21 July 2021

Published online: 22 September 2021

\section{References}

1. Karmacharya MS, Gupta VK, Tyagi I, Agarwal S, Jha VK. Removal of As (III) and $A s(V)$ using rubber tire derived activated carbon modified with alumina composite. J Mol Liq. 2016;216:836-44.

2. Yang R, Su Y, Aubrecht KB, Wang X, Ma HY, Grubbs RB, et al. Thiolfunctionalized chitin nanofibers for As (III) adsorption. Polymer. 2015;60:9-17.

3. Maiorino RM, Aposhian HV. Determination and metabolism of dithiolchelating agents: IV. Urinary excretion of meso-2,3-dimercaptosuccinic acid and mercaptosuccinic acid in rabbits given meso-2,3-dimercaptosuccinic acid. Biochem Pharmacol. 1989;38:1147-54.

4. Choong TSY, Chuah TG, Robiah Y, Koay FLG, Azni I. Arsenic toxicity, health hazards and removal techniques from water: an overview. Desalination. 2007;217:139-66.

5. Habuda-Stanic M, Nujic M. Arsenic removal by nanoparticles: a review. Environ Sci Pollut R. 2015;22:8094-123.

6. Anirudhan TS, Unnithan MR. Arsenic( $($ ) removal from aqueous solutions using an anion exchanger derived from coconut coir pith and its recovery. Chemosphere. 2007;66:60-6.

7. Mondal P, Bhowmick S, Chatterjee D, Figoli A, Van der Bruggen B. Remediation of inorganic arsenic in groundwater for safe water supply: a critical assessment of technological solutions. Chemosphere. 2013;92:157-70.

8. Waypa JJ, Elimelech M, Hering JG. Arsenic removal by RO and NF membranes. J Am Water Works Ass. 1997:89:102-14.

9. Duarte AALS, Cardoso SJA, Alcada AJ. Emerging and innovative techniques for arsenic removal applied to a small water supply system. Sustainability. 2009;1:1288-1304.

10. Kao AC, Chu YJ, Hsu FL, Liao VHC. Removal of arsenic from groundwater by using a native isolated arsenite-oxidizing bacterium. J Contam Hydrol. 2013; 155:1-8.

11. Pincus LN, Gonzalez IS, Stavitski E, Zimmerman JB. Aerobic oxidation of arsenite to arsenate by $\mathrm{Cu}(\mathrm{II})$-chitosan $/ \mathrm{O}_{2}$ in Fenton-like reaction, a XANES investigation. Environ Sci Wat Res. 2020;6:2713-22.

12. Wang L, Shi CX, Wang L, Pan L, Zhang XW, Zou JJ. Rational design, synthesis, adsorption principles and applications of metal oxide adsorbents: a review. Nanoscale. 2020;12:4790-815.

13. Tan XF, Liu SB, Liu YG, Gu YL, Zeng GM, Hua XJ, et al. Biochar as potential sustainable precursors for activated carbon production: multiple applications in environmental protection and energy storage. Bioresour Technol. 2017;227:359-72.

14. Zhi MJ, Liu SH, Hong ZL, Wu NQ. Electrospun activated carbon nanofibers for supercapacitor electrodes. RSC Adv. 2014;4:43619-23.

15. Beesley $L$, Marmiroli $M$. The immobilisation and retention of soluble arsenic, cadmium and zinc by biochar. Environ Pollut. 2011;159:474-80.

16. Xue YW, Gao B, Yao Y, Inyang M, Zhang M, Zimmerman AR, et al. Hydrogen peroxide modification enhances the ability of biochar (hydrochar) produced from hydrothermal carbonization of peanut hull to remove aqueous heavy metals: batch and column tests. Chem Eng J. 2012;200:673-80.

17. Hao LL, Zheng T, Jiang JP, Zhang GS, Wang P. Removal of As (III) and As(V) from water using iron doped amino functionalized sawdust: characterization, adsorptive performance and UF membrane separation. Chem Eng J. 2016;292:163-73.

18. Zhang M, Gao B, Yao Y, Xue YW, Inyang M. Synthesis of porous MgObiochar nanocomposites for removal of phosphate and nitrate from aqueous solutions. Chem Eng J. 2012;210:26-32.

19. Jindo K, Suto K, Matsumoto K, Garcia C, Sonoki T, Sanchez-Monedero MA. Chemical and biochemical characterization of biochar-blended composts prepared from poultry manure. Bioresour Technol. 2012;110:396-404. 
20. Tan GC, Sun WL, XU YR, Wang HY, Xu N. Sorption of mercury (II) and atrazine by biochar, modified biochars and biochar based activated carbon in aqueous solution. Bioresour Technol. 2016;211:727-35.

21. Paranavithana GN, Kawamoto K, Inoue Y, Saito T, Vithanage M, Kalpage CS, et al. Adsorption of $\mathrm{Cd}^{2+}$ and $\mathrm{Pb}^{2+}$ onto coconut shell biochar and biocharmixed soil. Environ Earth Sci. 2016;75:484.

22. Liu YC, Liu Q, Chen MY, Ma LL, Yang B, Chen J, et al. Evaluation of migration of heavy metals and performance of product during co-pyrolysis process of municipal sewage sludge and walnut shell. Environ Sci Pollut R. 2017;24:22082-90.

23. Zhao $B, X u X Y, X u S C$, Chen $X$, Li HB, Zeng FQ. Surface characteristics and potential ecological risk evaluation of heavy metals in the bio-char produced by co-pyrolysis from municipal sewage sludge and hazelnut shell with zinc chloride. Bioresour Technol. 2017;243:375-83.

24. Jin JW, Wang MY, Cao YC, Wu SC, Liang P, Li YN, et al. Cumulative effects of bamboo sawdust addition on pyrolysis of sewage sludge: biochar properties and environmental risk from metals. Bioresour Technol. 2017;228:218-26.

25. Huang HJ, Yang T, Lai FY, Wu GQ. Co-pyrolysis of sewage sludge and sawdust/ rice straw for the production of biochar. J Anal Appl Pyrol. 2017;125:61-8.

26. Lin LN, Song ZG, Liu XW, Khan ZH, Qiu WW. Arsenic volatilization in flooded paddy soil by the addition of Fe-Mn-modified biochar composites. Sci Total Environ. 2019;674:327-35.

27. Lagergren S. Zurtheorie der sogenannten adsorption gelosterstoffe. K Sven Vetenskapsakad Handl. 1898;24:1-39 [in German].

28. Gosset T, Trancart IL, Thevenot DR. Batch metal removal by peat. Kinetics and thermodynamics. Water Res. 1986;20:21-6.

29. Langmuir I. The adsorption of gases on plane surfaces of glass, mica and platinum. J Am Chem Soc. 1918:40:1361-403.

30. Freundlich H. Concerning adsorption in solutions. Z Phys Chem-Stoch Ve. 1906:57:385-470 [in German].

31. Venkatesha TG, Nayaka YA, Chethana BK. Adsorption of ponceau S from aqueous solution by MgO nanoparticles. Appl Surf Sci. 2013;276:620-7.

32. El-Sayed GO. Removal of methylene blue and crystal violet from aqueous solutions by palm kernel fiber. Desalination. 2011;272:225-32.

33. Son EB, Poo KM, Chang JS, Chae KJ. Heavy metal removal from aqueous solutions using engineered magnetic biochars derived from waste marine macro-algal biomass. Sci Total Environ. 2018;615:161-8.

34. Ma Y, Liu WJ, Zhang N, Li YS, Jiang H, Sheng GP. Polyethylenimine modified biochar adsorbent for hexavalent chromium removal from the aqueous solution. Bioresour Technol. 2014;169:403-8.

35. Kilic M, Apaydin-Varol E, Putun AE. Adsorptive removal of phenol from aqueous solutions on activated carbon prepared from tobacco residues: equilibrium, kinetics and thermodynamics. J Hazard Mater. 2011;189:397-403.

36. Jindo K, Mizumoto H, Sawada Y, Sanchez-Monedero MA, Sonoki T. Physical and chemical characterization of biochars derived from different agricultural residues. Biogeosciences. 2014;11:6613-21.

37. Kim J, Song J, Lee SM, Jung J. Application of iron-modified biochar for arsenite removal and toxicity reduction. J Ind Eng Chem. 2019;80:17-22.

38. Navarathna CM, Karunanayake AG, Gunatilake SR, Pittman CU, Perez F, Mohan D, et al. Removal of Arsenic (III) from water using magnetite precipitated onto Douglas fir biochar. J Environ Manage. 2019;250:109429.

39. Sattar MS, Shakoor MB, Ali S, Rizwan M, Niazi NK, Jilani A. Comparative efficiency of peanut shell and peanut shell biochar for removal of arsenic from water. Environ Sci Pollut R. 2019;26:18624-35.

40. Foo KY, Hameed BH. Insights into the modeling of adsorption isotherm systems. Chem Eng J. 2010;156:2-10.

41. Xu PA, Zeng GM, Huang DL, Yan M, Chen M, Jiang H, et al. Fabrication of reduced glutathione functionalized iron oxide nanoparticles for magnetic removal of Pb (II) from wastewater. J Taiwan Inst Chem E. 2017;71:165-73.

42. Feng YF, Yang F, Wang YQ, Ma L, Wu YH, Kerr PG, et al. Basic dye adsorption onto an agro-based waste material-Sesame hull (SesamumindicumL.). Bioresour Technol. 2011;102:10280-5.

43. Anayurt RA, Sari A, Tuzen M. Equilibrium, thermodynamic and kinetic studies on biosorption of $\mathrm{Pb}$ (II) and $\mathrm{Cd}$ (II) from aqueous solution by macrofungus (Lactariusscrobiculatus) biomass. Chem Eng J. 2009;151:255-61.

44. Chen CK, Nguyen NT, Duong CC, Le TT, Chen SS, Chang CT. Adsorption configurations of iron complexes on As (III) adsorption over sludge biochar surface. J Nanosci Nanotechnol. 2021;21:5174-80.

\section{Publisher's Note}

Springer Nature remains neutral with regard to jurisdictional claims in published maps and institutional affiliations.

Ready to submit your research? Choose BMC and benefit from:

- fast, convenient online submission

- thorough peer review by experienced researchers in your field

- rapid publication on acceptance

- support for research data, including large and complex data types

- gold Open Access which fosters wider collaboration and increased citations

- maximum visibility for your research: over $100 \mathrm{M}$ website views per year

At BMC, research is always in progress.

Learn more biomedcentral.com/submissions 